\title{
Papillary lesions of the breast
}

\author{
Janina Kulka ${ }^{1}$ - Lilla Madaras ${ }^{1,2} \cdot$ Giuseppe Floris $^{3} \cdot$ Sigurd F. Lax $^{4,5}$
}

Received: 21 May 2021 / Revised: 1 August 2021 / Accepted: 6 August 2021 / Published online: 3 November 2021

(c) The Author(s) 2021, corrected publication 2022

\begin{abstract}
Papillary lesions of the breast represent a heterogeneous group of lesions including benign papillomas, papillomas with focal epithelial atypia, fully fledged ductal carcinoma in situ (DCIS) or lobular neoplasia, papillary DCIS, encapsulated papillary carcinomas without or with invasion, solid papillary carcinomas, and invasive papillary carcinomas. A micropapillary pattern characterized by lack of fibrous stalks within the papillae is observed in micropapillary DCIS and invasive micropapillary carcinoma. In addition, a variety of other rare breast lesions reveals a papillary architecture such as tall cell carcinoma with reversed polarity (TCCRP) and mucinous cystadenocarcinoma, adenomyoepithelioma, and secretory carcinoma. In addition, benign lesions such as usual ductal hyperplasia, apocrine metaplasia, gynecomastia, and juvenile papillomatosis may show a papillary or micropapillary architecture. Fragments of a benign papilloma in a breast biopsy are considered a lesion of uncertain malignant potential (B3 in the European classification) and excision is mostly recommended. Although the knowledge about molecular pathology of papillary breast lesions has increased, there is not sufficient evidence for diagnostically useful molecular features, yet. The aim of this review is to provide an update on papillary and micropapillary lesions with emphasis on problematic areas for daily diagnostic work including biopsies.
\end{abstract}

Keywords Breast $\cdot$ Papillary lesions $\cdot$ Ductal carcinoma in situ $\cdot$ DCIS $\cdot$ Micropapillary $\cdot$ Biopsy

\section{Introduction}

Diagnostic difficulties in the management of papillary breast lesions have been reflected by an increasing number of publications in recent years, including review articles covering the most relevant diagnostic aspects, molecular characteristics and management strategies $[4,10,39,64,74,88]$.

Papillary breast lesions are a clinically, histologically, and biologically heterogeneous group of breast diseases. Their

Janina Kulka

kulka.janina@med.semmelweis-univ.hu

1 2nd Department of Pathology, Semmelweis University, Üllői út 93, 1091 Budapest, Hungary, E.U.

2 Department of Pathology, Uzsoki Hospital, Budapest, Hungary

3 Department of Imaging and Pathology, Laboratory of Translational Cell \& Tissue Research, KU Leuven, University of Leuven, University Hospitals Leuven, Leuven, Belgium

4 Department of Pathology, Hospital Graz II, Graz, Austria

5 School of Medicine, Johannes Kepler University, Linz, Austria main common histological feature is the presence of papillae mostly with arborising fibrovascular stroma. The formation of papillae is not a feature of normal breast tissue and the morphogenesis of papillary breast lesions is still not well understood [73]. It has been proposed that some papillary lesions result from a coordinated proliferation of stromal and epithelial cells, while in others the epithelial proliferation incorporates connective tissue of the involved duct's wall [73]. When a papillary breast lesion is diagnosed the most important question is whether the lesion is benign, a precursor or malignant and in addition whether it is invasive or non-invasive. To rule out invasive growth, the presence of myoepithelial cells is basically important. In benign papillary lesions, myoepithelial cells are present together with luminal cells along the fibrovascular cores; however, myoepithelial cells may be absent or scant in benign apocrine papillomas and papillary apocrine hyperplasia [21]. The occurrence of cellular atypia, particularly in an associated ductal carcinoma in situ (DCIS), is accompanied by reduction and even lack of myoepithelial cells. In papillary DCIS, myoepithelial cells are present only at the periphery of the involved ducts. Encapsulated papillary carcinomas lack myoepithelium along the cyst wall, as well as do the nests of solid papillary carcinomas and of frankly 
invasive papillary carcinoma. Biologically, most carcinomas with papillary features are ER-positive and HER2 negative. Two recently acknowledged entities, tall cell carcinoma with reversed polarity and mucinous cystadenocarcinoma, are often triple negative but most cases show a relatively good prognosis [26, 42]. In contrast to usual papillae, micropapillae lack a fibrovascular core. The presence of micropapillae in breast lesions is less common but also of practical importance since a micropapillary pattern may be associated with various lesions such as usual ductal hyperplasia, DCIS, and invasive carcinoma.

The diagnostic problems of papillary breast lesions are reflected in the external quality assurance scheme of the UK National Health Service Breast Screening. Papillary lesions belonged to the most frequently misinterpreted breast lesions and were, particularly, over- or underdiagnosed based on HE sections alone [74]. Furthermore, the diagnosis of papillary lesions on core needle or vacuum assisted biopsy may be challenging. Even if fragments of a benign papillary lesion are found in a biopsy specimen, the presence of cellular atypia in another part of the lesion cannot be completely ruled out. This diagnostic uncertainty has led in Europe to the categorization of benign papillary lesions in biopsies as lesions of uncertain malignant potential or B3 on a 5 scale, regardless of the presence of cellular atypia [69]. In addition, the diagnosis of atypical epithelial proliferations on a biopsy may be challenging.

In this review, we would like to address clinical, radiological, and pathological features, and if available also molecular characteristics of the most important papillary and micropapillary breast lesions. Another focus is also diagnostic difficulties and dilemmas on core- or vacuum-assisted biopsies particularly for intraductal papillomas including B classification.

\section{Papillary neoplasms in the WHO classification of breast tumors}

Figure 1 provides an overview on papillary neoplasms listed by the 2019 WHO classification of breast tumors with emphasis on special features and differential diagnosis.

\section{Intraductal papilloma}

Intraductal papillomas are benign intraluminal proliferations consisting of arborizing fibrovascular cores covered by a population of basal and luminal cells [85]. Intraductal papillomas are the most common papillary breast lesions and may be centrally or peripherally located. In a subset of cases, atypical epithelial proliferation may occur and is classified based on its extent as intraductal papilloma with atypical ductal hyperplasia
$(\mathrm{ADH})$ or with DCIS. Intraductal papilloma without atypical proliferation is also designated as NOS [85]. Most papillomas occur in perimenopausal women within an age range between 30 and 50 years. Central papillomas are more common than peripheral papillomas. They are not always identified on mammography. Larger lesions may appear as well-defined round or oval soft tissue opacities with or without microcalcifications. Ultrasound may reveal an intraluminal growth. Often, serous or sanguinolent nipple discharge is present. Galactography helps to identify the affected duct by showing filling defects caused by the intraductal growth. Peripheral papillomas are smaller, often multiple and usually asymptomatic. They may be associated with microcalcifications detected on mammography.

Histologically, complex arborizing fibrovascular cores lined by myoepithelial cells and covered by luminal cells are present within a dilated ductal space (Fig. 2). This evidence of two cell types is the hallmark for benign papillary lesions and absent in premalignant lesions [9]. The epithelial cells are either cuboidal or columnar, the nuclei may show intranuclear inclusions. In large papillomas, hemorrhage and infarcts may be present either due to prior needle biopsy or torsion of fibrovascular cores. Sclerosis and stromal fibrosis may imitate a pseudo-infiltrative pattern, and, particularly, in these cases myoepithelial markers may be very helpful (Fig. 3). Squamous, apocrine, mucinous, and chondroid metaplasia may occur and occasionally, collagenous spherulosis may also be present [85]. In peripheral papilloma, epithelial proliferation such as usual type ductal hyperplasia (UDH), ADH, atypical lobular hyperplasia (ALH), and DCIS is more common. High molecular weight cytokeratins (CK5, CK14) and heterogeneous positivity for estrogen receptor (ER) can be helpful to exclude atypical epithelial proliferation. Intraductal papillomas arising in the axillary tail need to be differentiated from rare sweat gland papillary hidradenoma. Care must be taken not to over-diagnose displaced epithelial elements of a papilloma into the surrounding breast parenchyma following fine needle aspiration- or core biopsy. The presence of hemosiderin, inflammatory cells, histiocytes, granulation tissue, or cellular scar tissue may be good indicators for an artifact. In the case of adenomatous growth pattern, adenomyoepithelioma may be considered. Differentiation from nipple adenoma may be challenging in cases of centrally located papilloma with sclerosing features. However, nipple adenoma arises mostly from the dermo-epidermal junction and less frequently from large ducts [85].

\section{Intraductal papilloma with ADH, DCIS, or lobular neoplasia}

These lesions harbor a low nuclear grade atypical epithelial proliferation covering a part of the papilloma. In intraductal papilloma with $\mathrm{ADH}$, this proliferation is limited to $<3 \mathrm{~mm}$ 

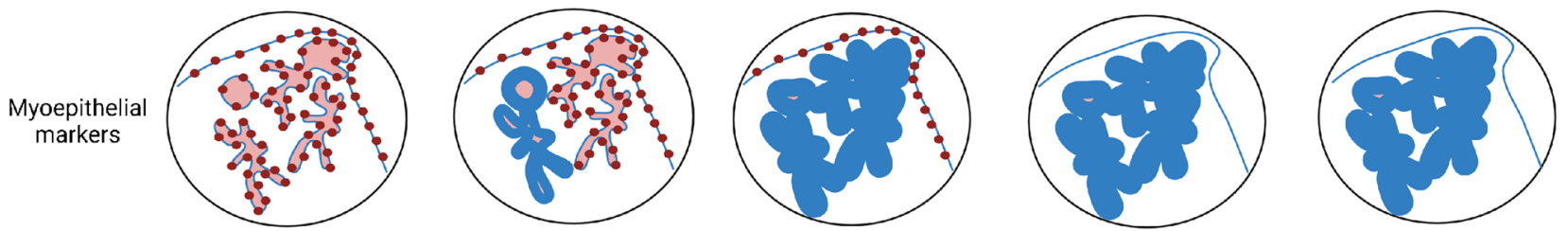

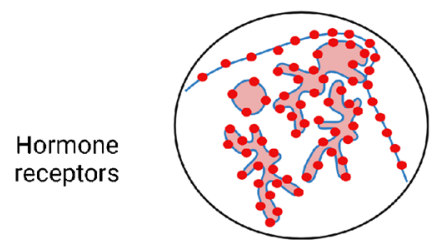

Type of

Intraductal

Papilloma

lesion

B category

on CNB

Differential
diagnosis

\section{$\mathrm{B} 2$ or $\mathrm{B} 3$}

depending

on size

Papillary DCIS

Nipple adenoma

Papillary hydradenoma

Adenomyoepithelioma

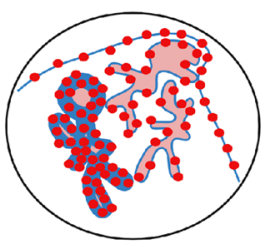

Papilloma with $\mathrm{ADH}^{\circledR}$ Papilloma with DCIS§

B3@

B5as

Papilloma@§

Papilloma with $\mathrm{ADH}^{\S}$

Papilloma with DCIS@

Adenomyoepithelioma

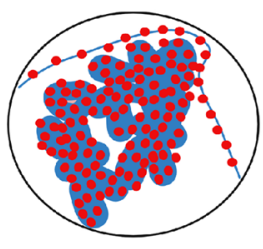

Papillary DCIS

B5a

Papilloma

Papilloma with $\mathrm{ADH}$

Papilloma with DCIS

Adenomyoepithelioma

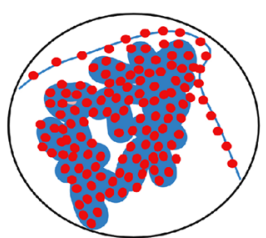

Encapsulated papillary carcinoma

B5a

Solid papillary carcinoma Cystadenocarcinoma Papillary DCIS Papilloma with DCIS

pocrine papillary hyperplasia (caveat: absence of myoepithelial cells)

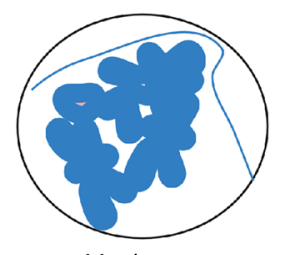

Mucinous

cystadenocarcinoma*

Secretory carcinoma (with papillary architecture)

$\mathrm{B} 5 \mathrm{a} / \mathrm{b}$

Metastatic mucin producing tumors*

Encapsulated papillary carcinoma*

Pure mucinous breast carcinoma*

IBC-NST $\$$

Apocrine carcinomas
Fig. 1 Staining patterns of myoepithelial markers and hormone receptors in various papillary lesions of the breast. The presence of myoepithelial markers is illustrated by bordeaux brown dots. Myoepithelial cells may be present or not in the peripheral wall and/or centrally in association with the branching fibrovascular cores illustrated in pink. In the same fashion, the bright red dots highlight the expression of hormone receptors in the lining epithelium. The lining epithe-

of extent, whereas in intraductal papilloma with DCIS, it spans $\geq 3 \mathrm{~mm}$. The term "atypical papilloma" has not been adopted by the recent WHO classification. There are no specific clinical or imaging features. Suspicious microcalcifications may be found on mammography.

The atypical ductal proliferation consists of cells with uniform, hyperchromatic nuclei often in cribriform arrangement (Fig. 4). Basally differentiated cells are not present. Immunohistochemistry underlines the neoplastic proliferation of luminal differentiated cells which are negative for high molecular weight keratins (CK5, CK14) and strongly and uniformly positive for ER. DCIS may be limited to the papilloma or may also involve the adjacent breast tissue [11]. If intermediate or high-grade atypia is present in a papilloma, the lesion should be classified as papilloma with DCIS regardless of the size of the atypical epithelial proliferation [11]. The risk of synchronously associated DCIS (or rarely that of invasive carcinoma) after diagnosis of papilloma in core needle biopsy is basically determined by the detection (or absence) of atypical epithelial proliferation [20]. lium is illustrated with a continuous blue line which depending on the degree of proliferation, and malignancy of the lesion becomes thicker with almost disappearance of the pink fibrovascular cores. Each combination of staining patterns is associated to specific lesions for which the B category on $\mathrm{CNB}$, and the differential diagnosis is proposed. (This figure was created with BioRender.com)

The risk of "upgrade" of a papilloma without atypia after CNB in diagnostic excision is $2-3 \%$ [11]. The corresponding upgrade rate of a papilloma with atypical epithelial proliferation after CNB in diagnostic excision is $5.11 \%$, and the upgrade rate after CNB with isolated atypical epithelial proliferation is $4.17 \%$ [46]. The risk of recurrence is more closely related to the presence of DCIS in the surrounding breast tissue than to the papilloma itself.

Less frequently, foci of lobular neoplasia may be present within an intraductal papilloma and this should be included in the pathology report (Fig. 4). E-cadherin and/or immunohistochemistry for catenin (p120 or $\beta$-catenin) may be helpful to highlight the area of lobular type atypia [11]. Intraductal papilloma with lobular neoplasia diagnosed on $\mathrm{CNB}$ or $\mathrm{VAB}$ does not require excision if radiological and pathological findings are concordant [11].

Earlier molecular studies suggested that alterations of c-Met, RET/PTC, $\alpha 3 \beta 1$ integrin, Sonic hedgehog (Shh), and Bone Morphogenetic Protein (BMP) play a role in the development of papillary breast lesions [71]. Recently, 
Fig. 2 Papilloma in a large duct (central location) showing sclerotic areas (A and $\mathbf{B})$. A prominent myoepithelial cell layer highlights the typical "two cell types" of benign papillary lesions (C). Myoepithelial cells can be demonstrated by $\mathrm{p} 63$ immunoreactivity both at the peripheral wall and along the fibrovascular cores (D)
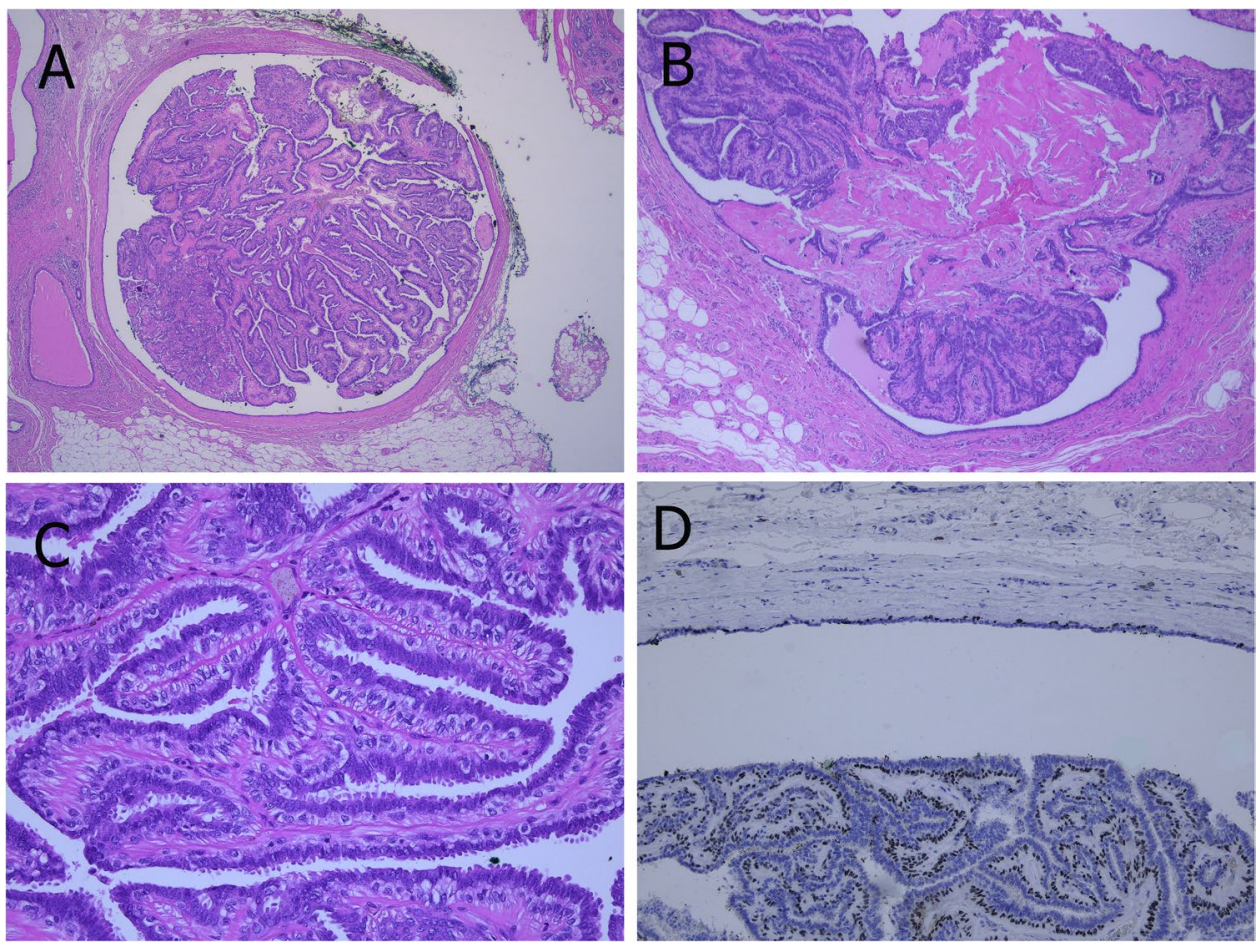
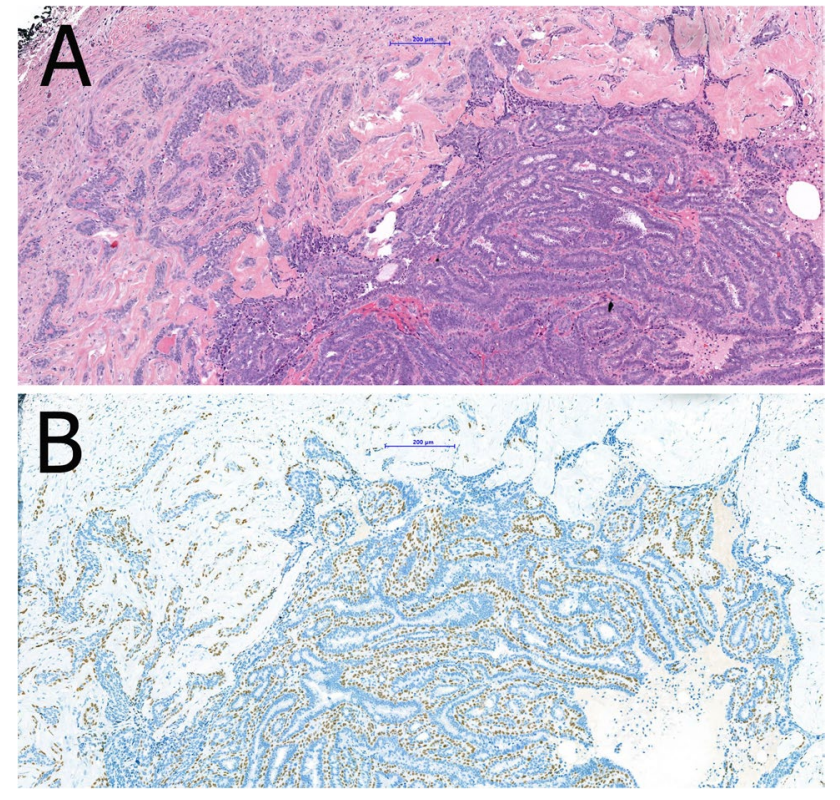

Fig. 3 Sclerosis of the papilloma's capsule with entrapped epithelial and myoepithelial cells may mimic a pseudo-infiltrative pattern (A). Myoepithelial markers such as p63 demonstrate the presence of myoepithelial cells and exclude invasion $(\mathbf{B})$

progression to DCIS and invasive carcinoma was hypothesized for a subset of intraductal papilloma [40]. Intraductal papillomas were clonally related to synchronous DCIS and invasive carcinoma in more than 50\%, even without papillary histology of the latter. In pure intraductal papillomas, the most common finding was loss of chromosome $\mathrm{X}$, followed by loss of 16q and 7q. The most common mutation was PIK3CA activating missense mutation. Increasing copy number alterations, especially 1q gain, 16q loss, and 11q loss, seem to result in progression. It was suggested that an intraductal papilloma without PIK3CA mutation could progress directly to papilloma with ADH/DCIS.

\section{Clinical management of intraductal papillomas detected on CNB and VAB}

According to the European classification system, diagnostic $\mathrm{CNB}$ and VAB containing fragments of intraductal papillomas are coded as B3 and, due to the histomorphological heterogeneity of papillomas, excision is recommended [7, $45,77]$. However, the upgrade rate to DCIS and invasive carcinoma after surgery is low and varies between 0 and $16 \%$ (Table 1) [13, 15, 43, 49, 52, 58, 60, 62, 66]. Recent studies investigated upgrade rates and necessity of excision versus only imaging follow-up after biopsy. High risk lesions were found in $9.5 \%$ of 327 intraductal papillary lesions undergoing excision, DCIS in $3.4 \%$, and invasive carcinomas in $2.4 \%$ [43]. Upgrade to DCIS or invasive carcinoma was more common among women over the age of 50 years, with lesions $>1 \mathrm{~cm}$, lesions presenting as palpable mass, or if the lesion was $>5 \mathrm{~cm}$ distant from the nipple [43]. Among 61 patients under follow-up by imaging, no cancers were detected. In another recent study, features predicting upgrade were older age (median 64 versus 55), 
Fig. 4 Intraductal papilloma with atypical epithelial proliferation of ductal type in an area of $<3 \mathrm{~mm}$ size qualifying for the diagnosis of $\mathrm{ADH}(\mathbf{A})$. The atypical epithelial proliferation lacks CK5 immunoreactivity (B). Intraductal papilloma with lobular neoplasia characterized by a solid proliferation of monomorphic cells with reduced cell cohesion (C, D). The lobular neoplasia is characterized by lack of immunoreactivity for CK5 (E) and e-cadherin (F)

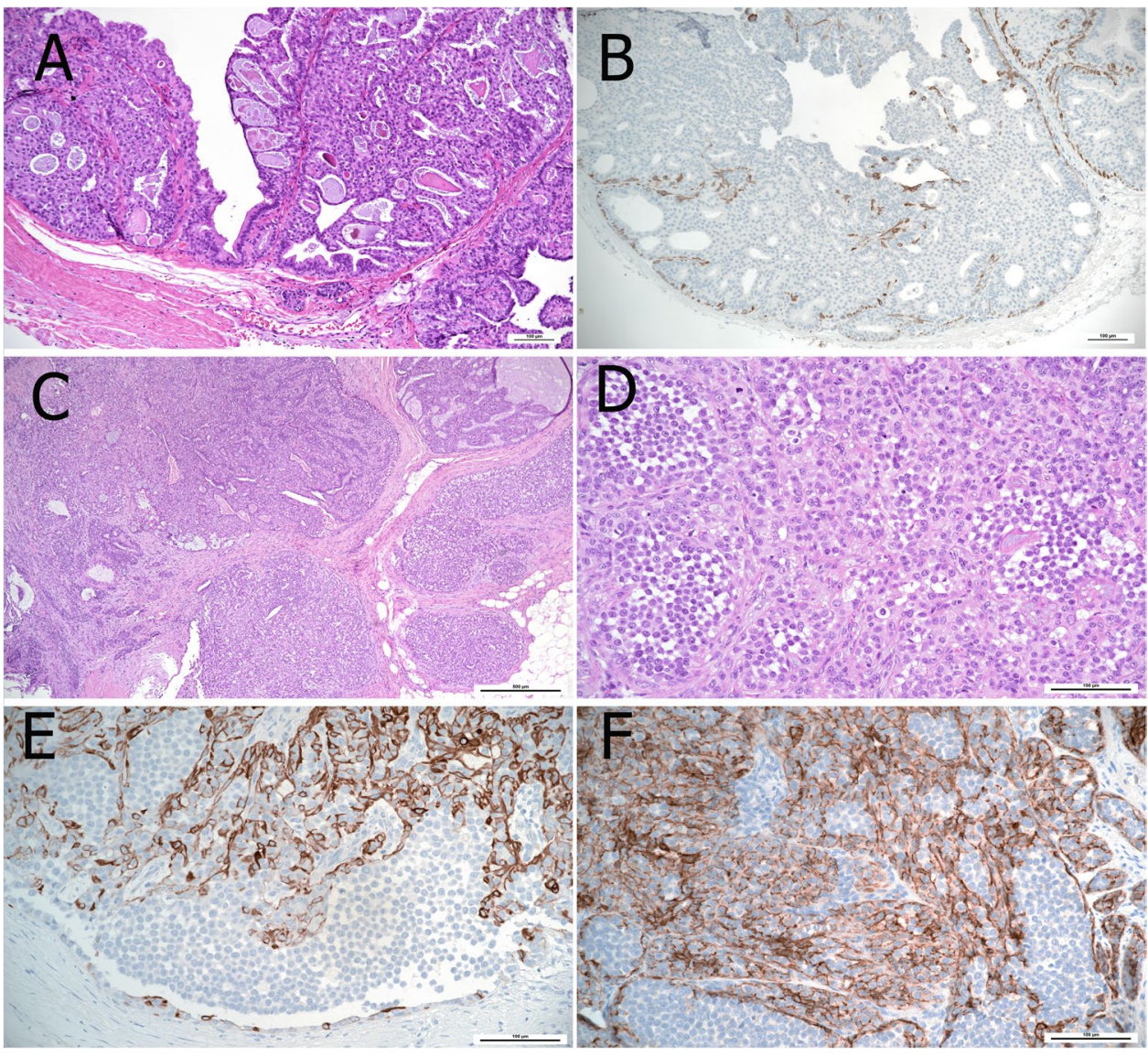

higher BIRADS category $(\geq 4)$, lesion size $(\geq 0.5 \mathrm{~cm})$, and mass lesions with calcifications [52]. It was suggested that in particular, younger women with non-mass abnormalities and low BIRADS categories may benefit from clinical and imaging follow-up alone [52]. In a recent series analyzing symptomatic cases only, a general $2.4 \%$ upgrade rate was found with an upgrade to ADH and $\mathrm{LN}$ of $12.1 \%$, but no predictive features for upgrade were identified [60]. It was suggested that if the whole lesion is removed by VAB and lacks atypia, there is no need for further surgery. No upgrade to malignancy was found if the benign papillary lesion was diagnosed on $11 \mathrm{G} \mathrm{VAB}$ and followed by excision [15]. Only the presence of atypia in a papilloma and older age were associated with upgrade to malignancy. Nevertheless, long-term follow-up is recommended [8]. In summary, these studies challenge the necessity of general excision of papillomas due to low upgrade rates. In 2018, the Second International Consensus Conference on lesions of uncertain malignant potential in the breast (B3 lesions) concluded that surveillance is appropriate for intraductal papillomas fully removed by VAB. Larger lesions which cannot be completely removed by VAB need open surgery and postoperative surveillance. In contrast, small papillomas $(<2 \mathrm{~mm})$ may be coded as B2, if no atypia is present and if in toto removal can be safely diagnosed [69]. Since multiple (more than 5) papillomas were shown to bear a threefold increased relative risk for subsequent development of breast cancer, long-term followup is recommended after surgical removal. The relative risk increases to sevenfold, if multiple papillomas are associated with ADH or LN [46]. We would like to suggest to use the term "papilloma with atypical ductal epithelial proliferation (ADEP)" for biopsies and to restrict "papilloma with ADH/ DCIS to excision specimens.

\section{Papillary ductal carcinoma in situ}

Papillary ductal carcinoma in situ (DCIS) is a rare subtype of DCIS with papillary architecture completely lined by neoplastic ductal epithelium. Like other subtypes of DCIS, papillary DCIS is a segmental disease and involves small or large ducts in central and peripheral locations. It is usually detected on mammography due to associated microcalcifications or the presence of nodular densities.

The neoplastic epithelium is monomorphic and composed of one or several layers usually of columnar cells covering delicate branching fibrovascular cores (Fig. 5). Solid, cribriform, and micropapillary areas may be present. Myoepithelial cells are only present at the periphery of the ducts. The nuclear grade is usually low or intermediate. There is no 


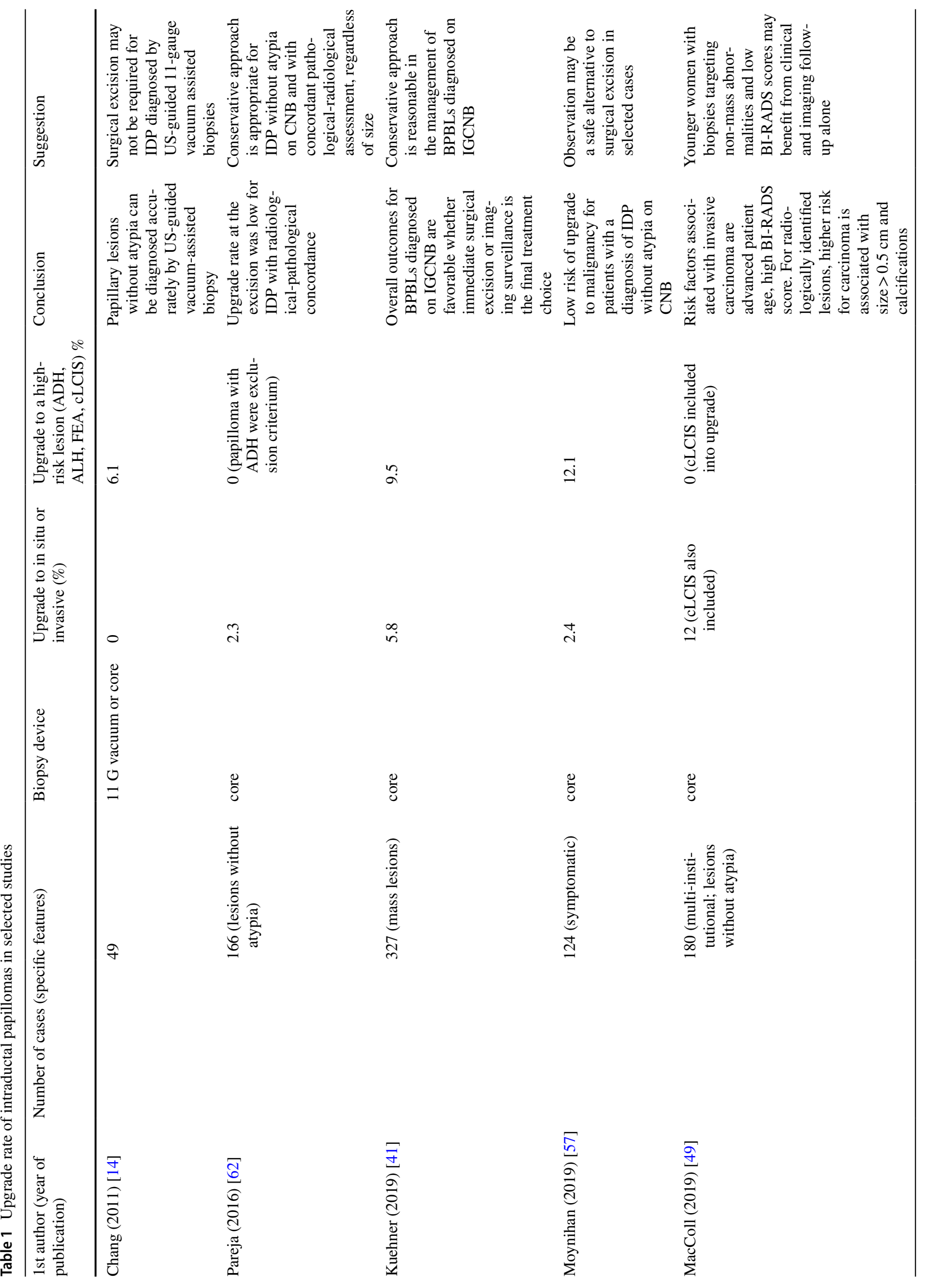




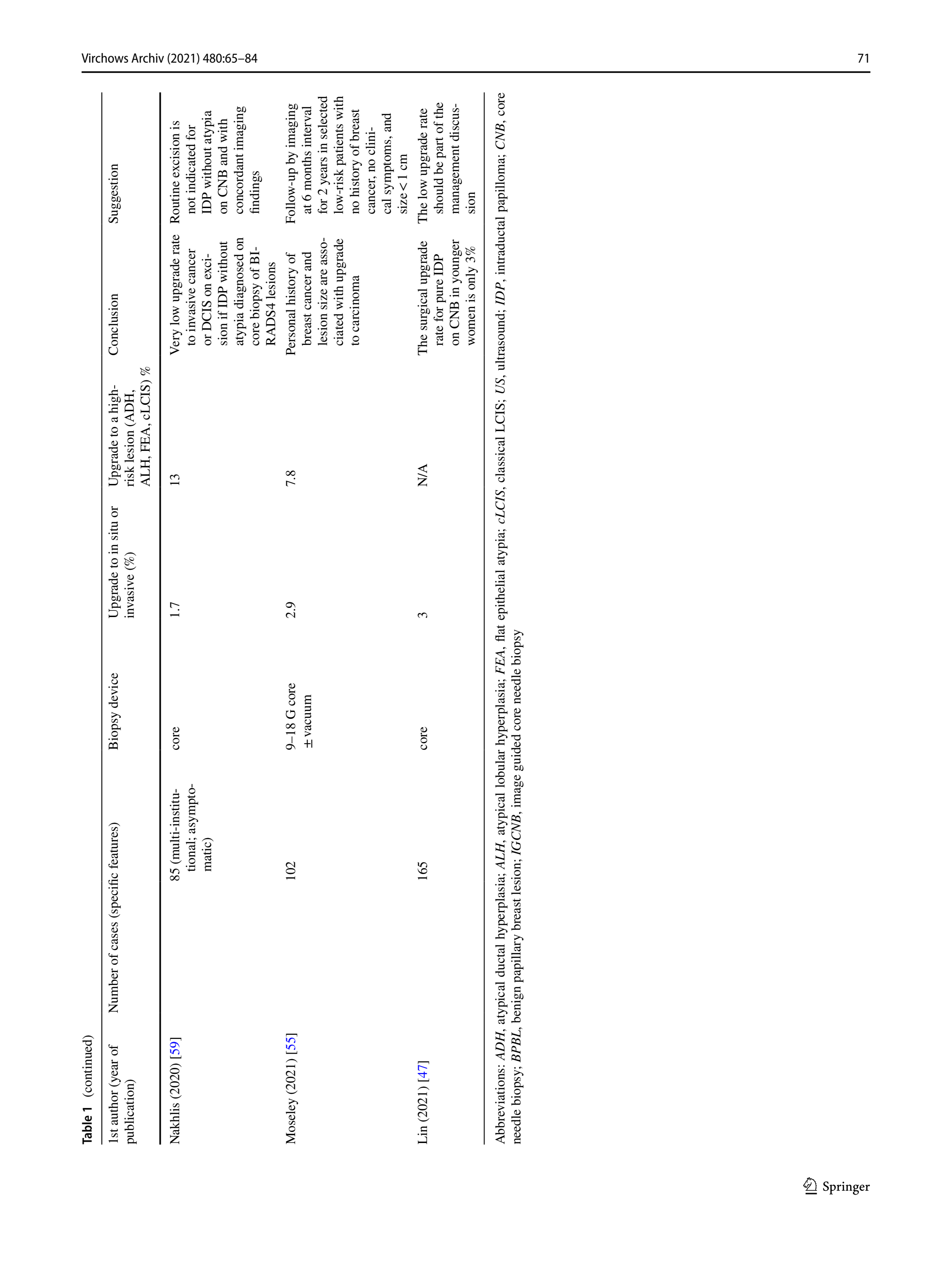


evidence of pre-existing benign intraductal papilloma [20]. Papillary DCIS usually occurs together with other DCIS patterns, pure papillary DCIS is rare. A peculiar dimorphic variant has been described showing so-called "globoid cells" that can be mistaken for myoepithelial cells but are negative for all myoepithelial markers in immunohistochemistry [20]. Studies describing molecular alterations of pure papillary DCIS are scarce. They share some genetic alterations found in low-grade DCIS of other architecture. Studies of papillary breast lesions including invasive papillary carcinomas revealed $\mathrm{LOH}$ at loci $16 \mathrm{q} 12.2,16 \mathrm{q} 21$, and $16 \mathrm{q} 23$, but $\mathrm{LOH}$ at the TP53 locus only in malignant papillary lesions [24, 93].

\section{Encapsulated papillary carcinoma}

Encapsulated papillary carcinoma (EPC) is a tumor characterized by pushing borders and a papillary, cribriform or solid growth within a cyst. EPC usually presents as a slowly growing, indolent palpable mass with bloody discharge in postmenopausal women, rarely in men. Imaging commonly reveals a well-circumscribed, round, or oval retro-areolar lesion. The disease course is indolent with exceptional occurrence of axillary lymph node metastases [61, 75].

EPC consists of monomorphic cells with low to intermediate grade nuclei covering fine fibrovascular cores or occasionally forming cribriform or micropapillary structures (Fig. 6) [50]. EPC usually lacks myoepithelial cells in the papillae and at the periphery that suggests the possibility of an expansile growth pattern [19]. Infrequently, an incomplete myoepithelial cell layer may be seen [92]. EPC is usually surrounded by a thick fibrous capsule, sometimes with entrapped tumor cells. The tumor cells are usually ER and progesterone receptor (PR) positive and lack HER2 amplification. Low or intermediate nuclear grade DCIS, usually with micropapillary or cribriform architecture, may be seen in the surrounding breast tissue. EPC may be associated with invasive NST carcinoma, less frequently cribriform, mucinous, or tubular carcinoma, beyond the capsule. In the absence of a frank invasive carcinoma, EPC should be staged and managed as DCIS [41]. Those rare tumors with expansile growth pattern and papillary architecture, but high nuclear grade features and high mitotic activity should be staged and managed as invasive breast cancer [76].

Genomic characterization of EPC revealed frequent PIK3CA mutations similar to low grade, ER-positive invasive breast carcinomas [25]. By PAM 50, the majority of EPC is classified as luminal A tumors and only a small number as luminal B. Furthermore, EPC seems to differ from solid papillary carcinoma and invasive papillary carcinoma by downregulation of genes related to cell migration [68].

\section{Solid papillary carcinoma}

Solid papillary carcinoma (SPC) is characterized by a solid growth pattern with delicate fibrovascular cores. Most SPC are unifocal and well circumscribed. They often are centrally located and cause nipple discharge. The prognosis is excellent with rare recurrence and only exceptional death of disease.

The histological features were described as in situ solid growth pattern filling large or dilated small ducts showing delicate fibrovascular septa that are sometimes sclerotic
Fig. 5 Papillary DCIS (A) with microinvasion (*). Cribriform architecture is present at the periphery of involved ducts (B). Characteristic features are low-grade nuclei $(\mathbf{C})$, lack of myoepithelial cells as demonstrated by p63 (D) and diffuse, strong ER positivity (E)

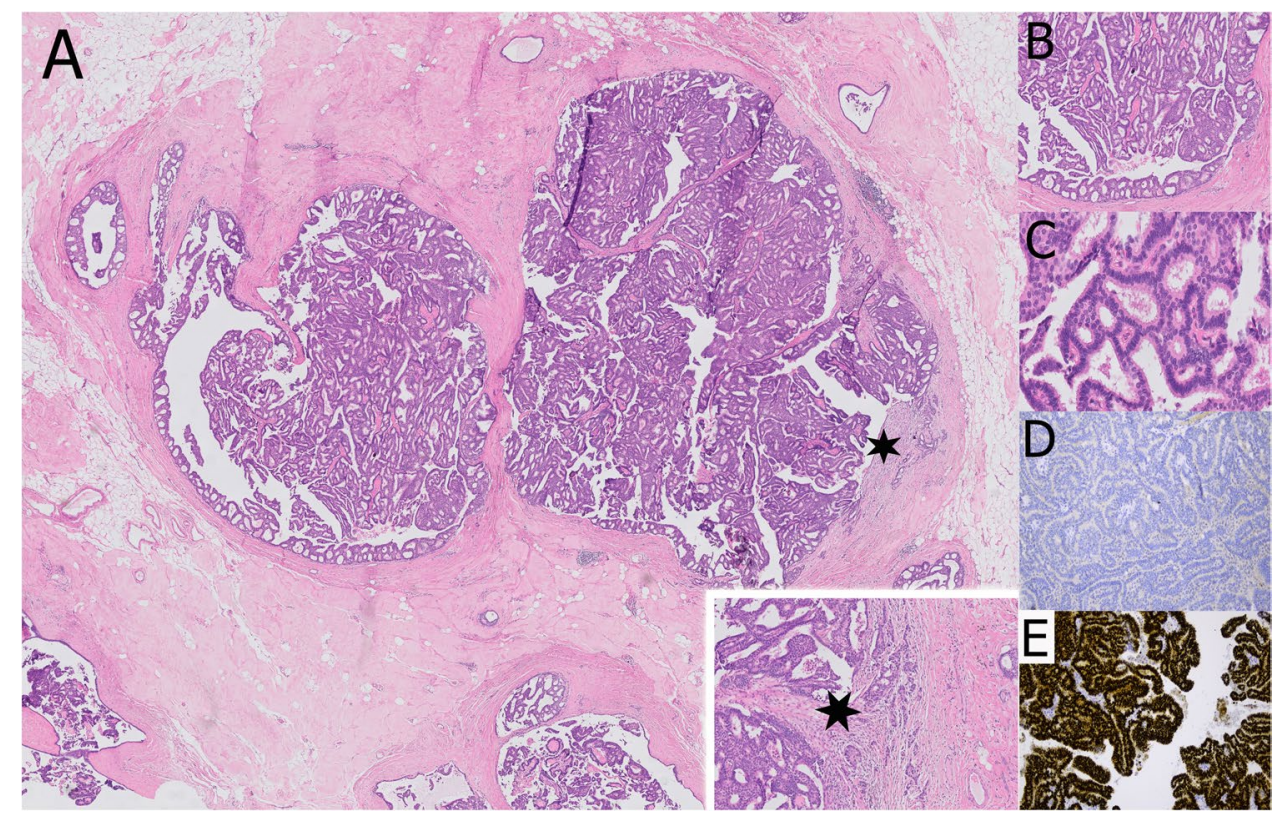


Fig. 6 Encapsulated papillary carcinoma with typical gross appearance (A). An arborizing papillary structure lined by low-grade atypical epithelium is present within a cystically dilated space surrounded by a fibrotic capsule (B) and may be associated with frank invasion (C)

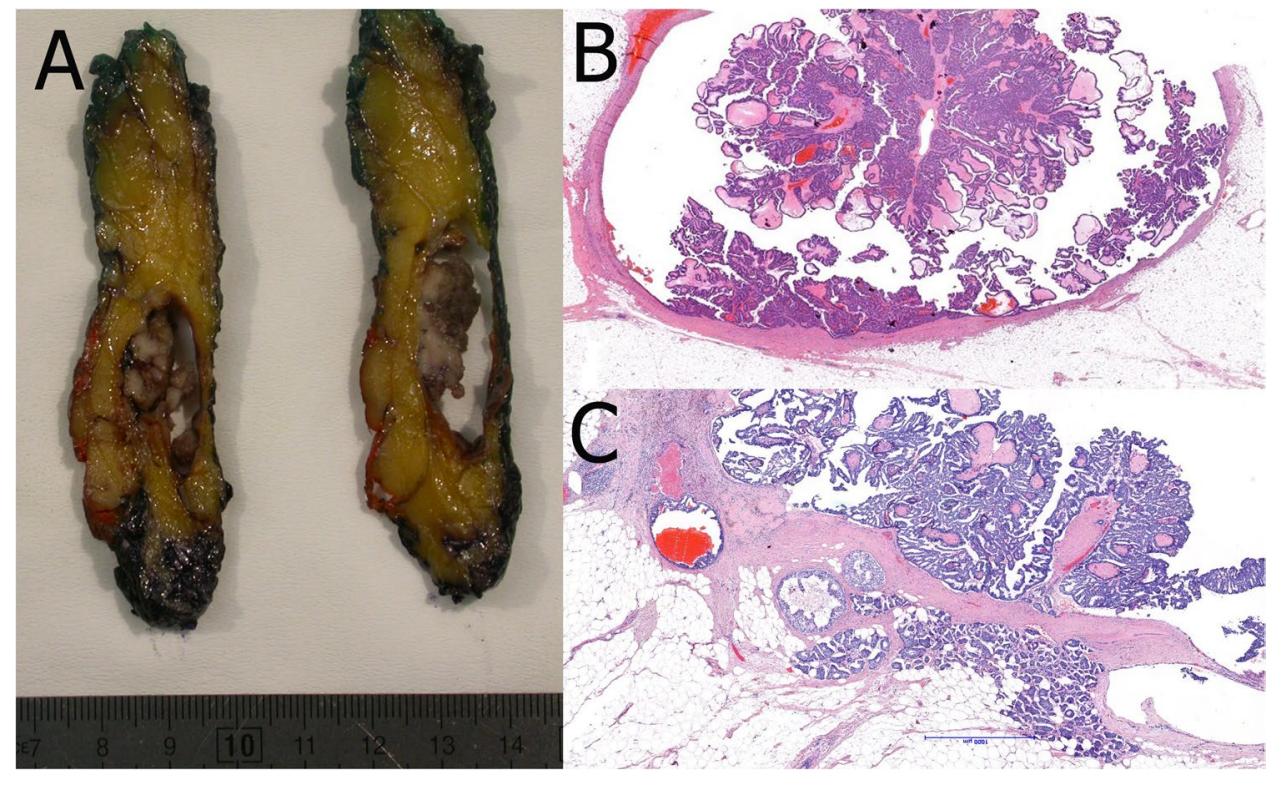

and nuclear palisading at the stromal epithelial interface (Fig. 7). Small- to moderate-sized cells with commonly round to ovoid or sometimes spindle-shaped, mildly atypical nuclei, and eosinophilic and granular cytoplasm are arranged in rosette or pseudo-rosette formations [53]. Neuroendocrine differentiation and mucin production are very common [65]. ER is diffusely and strongly positive. The complete absence of myoepithelial cells should not prevent from considering these tumors as in situ disease in presence of microscopic findings consistent with DCIS (e.g., rounded well-circumscribed structure in an organoid pattern). Rarely, tumors with features of SPC may show frank invasion and should be classified as invasive; this may be associated with a jigsaw pattern and a desmoplastic stromal response [51]. Invasion may also be associated with mucinous differentiation or present as carcinoma of no special type (NST) [51]. Invasive lobular carcinoma (ILC) mimicking SPC has been described in the differential diagnosis to SPC and also EPC but the small number of reported cases allows only limited conclusions [72]. Importantly, SPC-like ILC is a frankly invasive tumor [59].

Molecular studies included only a limited number of cases. No differences in copy number alterations were found between SPC, EPC, and invasive papillary carcinoma [68]. However, genes related to neuroendocrine differentiation ( $R E T, A S C L 1$, and $D O K 7$ ) were upregulated in SPC compared to EPC. Interestingly, all 4 cases analyzed by PAM50 were assigned to the luminal B subtype [68]. In another study using Oncotype DX, all SPC were associated with low and intermediate recurrence score (RS) [86]. One case of SPC-like ILC revealed an ILC-like molecular profile and a unique $C D H 1 / E$-cadherin mutation [17].

\section{Invasive papillary carcinoma}

Invasive papillary carcinoma is a very rare subtype of invasive breast carcinomas consisting of papillae with a fibrovascular core. There are no specific clinical or imaging findings. The papillae are located in dilated ducts and microcysts and lack myoepithelial cells at the periphery (Fig. 8). Tubules may be present. The nuclei are usually low grade with low to moderate number of mitoses. Invasive papillary carcinoma needs to be distinguished from invasive micropapillary carcinoma and other papillary tumors of the breast as well as from metastases of carcinomas with a papillary pattern (see below).

\section{Other breast tumors with papillary architecture}

\section{Tall cell carcinoma with reversed polarity}

Tall cell carcinoma with reversed polarity (TCCRP) has been formerly known as breast tumor resembling the tall cell variant of papillary thyroid carcinoma and as solid papillary carcinoma with reverse polarity. TCCRP is a rare subtype of invasive breast carcinoma consisting of tall columnar cells with reversed nuclear polarity arranged in a solid pattern. TCCRP usually presents as a well-circumscribed mass, measuring up to $5 \mathrm{~cm}$ in diameter. 

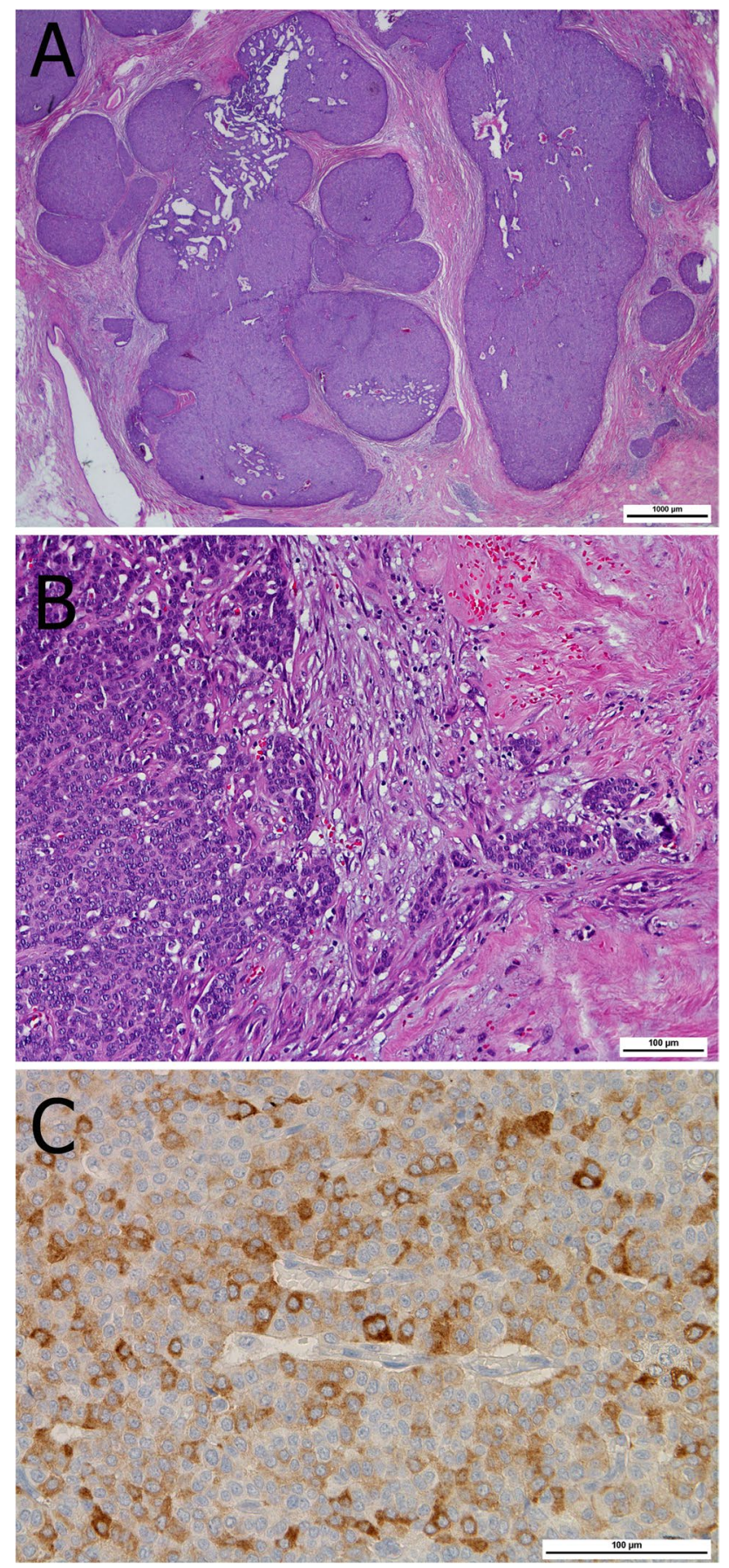

Fig. 7 Solid papillary carcinoma characterized by a low-grade atypical epithelial proliferation with solid growth pattern filling dilated ducts (A). Invasion is characterized by small infiltrative ducts and nests (B). Neuroendocrine differentiation is frequently found as confirmed by expression of synaptophysin $(\mathbf{C})$

The close resemblance to papillary thyroid carcinomas results from its frequent demonstration of papillae and follicular structures, even with colloid-like material, psammoma bodies, tumor cell nuclei with grooves and inclusions
(Fig. 9). The tumor cells are tall columnar with prominent eosinophilic cytoplasm rich in mitochondria. The nuclei are located at the apical areas of the cells hence the "reversed polarity" appearance. Myoepithelial cells are almost always missing. Foamy macrophages are often present within the fibrovascular cores. TCCRP is usually triple negative or weakly ER/PR-positive but with low Ki67 labeling index. Immunohistochemistry for calretinin is usually positive and negative for synaptophysin, chromogranin A, TTF1 and thyroglobulin. GATA3, GCDFP15, and mammaglobin are variably positive $[5,83]$.

A characteristic hotspot mutation R172 in the $I D H 2$ gene, which is otherwise rare in breast carcinomas, was detected in the vast majority of TCCRPs. Mutant $I D H 2$ can be detected by immunohistochemistry using a specific antibody [94]. Other tumors harbor PRUNE2 mutations. Missense mutations affecting PIK3CA or PIK3RI may also be detected. $B R A F$ mutations are not encountered.

\section{Mucinous cystadenocarcinoma}

Mucinous cystadenocarcinoma (MCA) is a very rare cyst-forming invasive breast carcinoma with papillae and abundant extracellular mucin (Fig. 10). So far, less than 35 cases have been published with predominance of Asian women [90]. The low number of cases could be explained by under-recognition. MCA usually occurs in postmenopausal women as a palpable mass with a relatively large diameter being $\geq 4 \mathrm{~cm}$ in $50 \%$ of the cases [38]. MCA is well circumscribed and often hypoechoic on ultrasound. The typical gross appearance is a gelatinous cyst. A prominent papillary architecture with swollen fibrovascular cores is often present and the papillae show hierarchical organization. An association with mucocelelike structures is frequent. Tumor cells are columnar with basally located nuclei, tufting, stratification, and abundant mucin production. Squamous morules or floating micropapillary groups may be observed at the tip of papillary projections and are considered a useful microscopic clue to distinguish MCA from other mucinous carcinomas of the breast [82]. Nuclear atypia is variable within the same lesion [42]. When DCIS is absent, metastatic origin should be ruled out because of overlapping features with pancreatic, appendiceal, and ovarian mucinous neoplasms. A panel of immunohistochemical markers including CK7, CK20, CDX2, and GATA3 is helpful. In contrast with pure mucinous carcinoma and EPC, which typically express ER and PR, MCA is triple negative [35, 90]. The majority of MCA has been treated by radical mastectomy; data regarding the need of systemic adjuvant therapy are missing. Lymph node involvement is rare in MCA and prognosis is considered favorable. However, the low level 
Fig. 8 Invasive papillary carcinoma characterized by cystically dilated spaces of various size (A) and frank invasion with focal necrosis at the periphery (B). Delicate arborizing papillary structures are readily appreciated at medium power magnification $(\mathbf{C})$

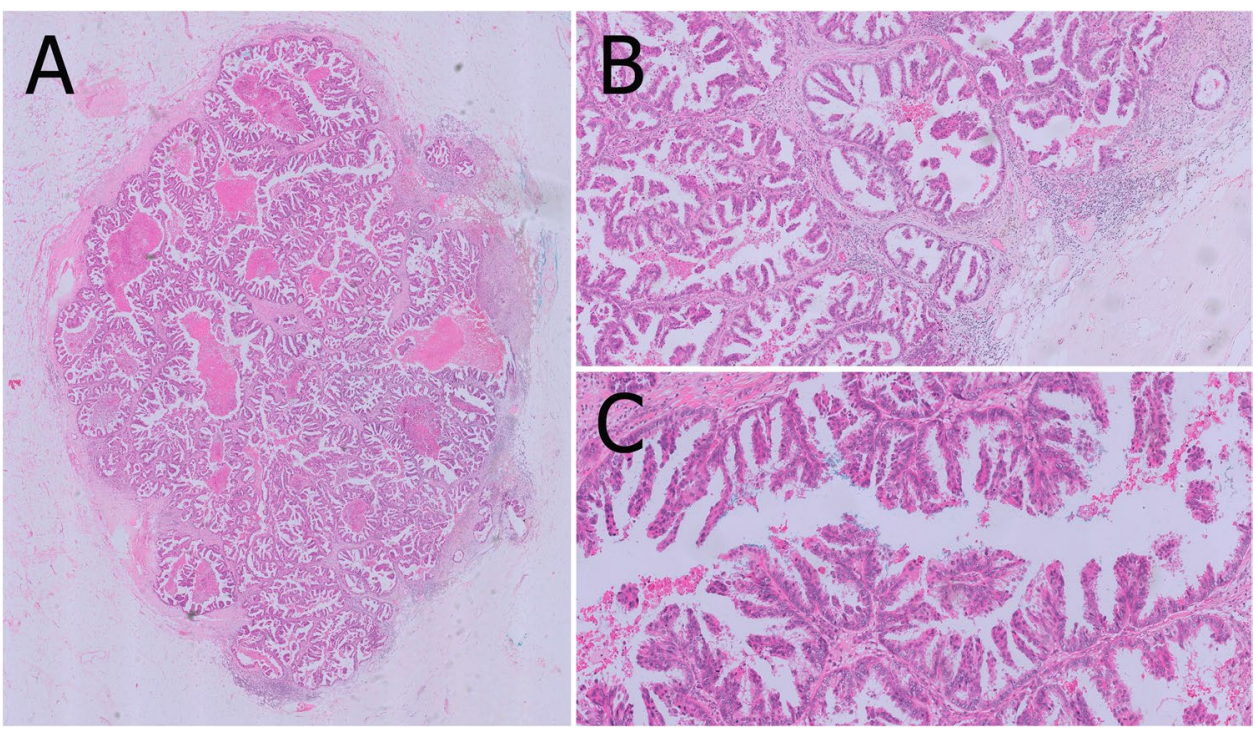

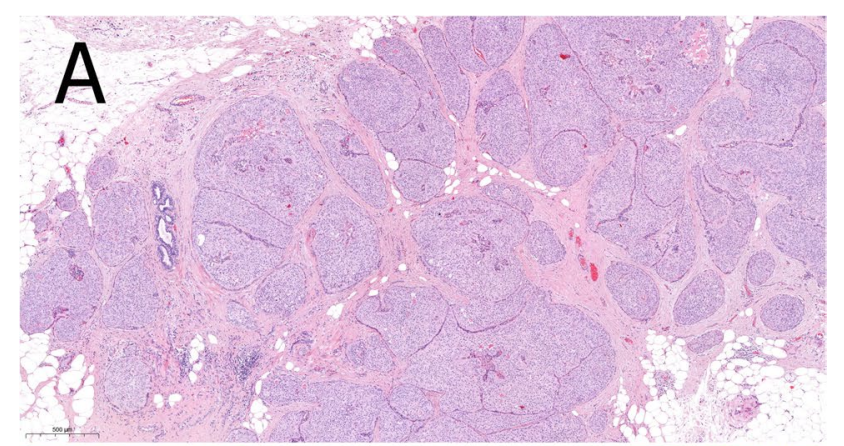
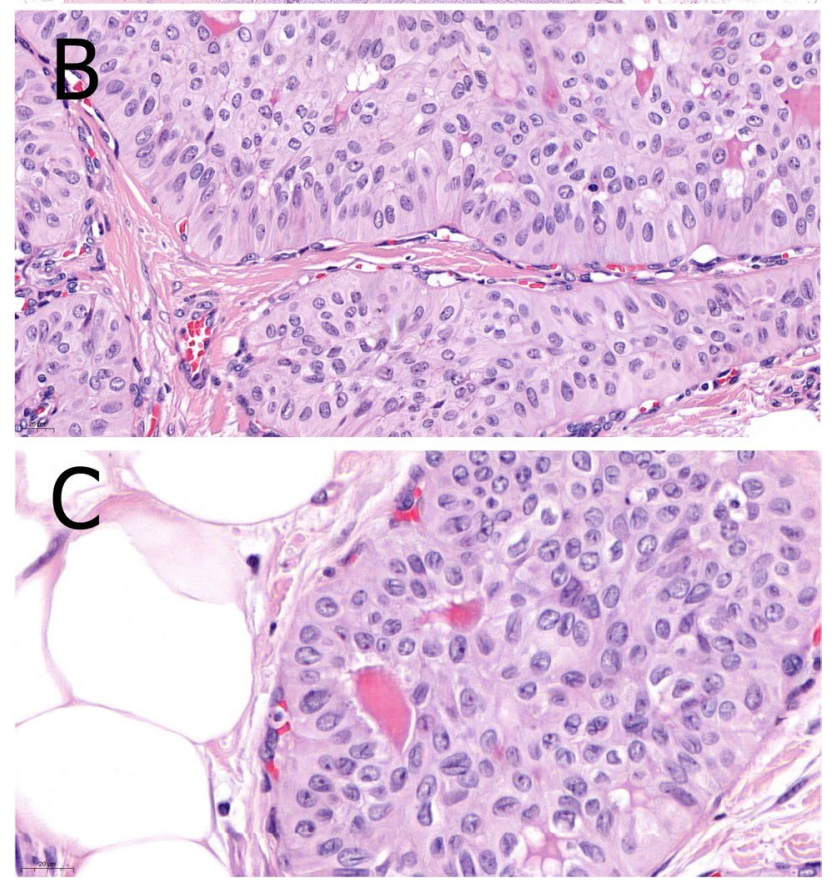

Fig. 9 TCCRP showing multinodular architecture with presence of fibrovascular cores centrally located in the nodular structures (A). Narrow fibrous septae (B) and occasionally colloid-like eosinophilic material $(\mathbf{C})$ are characteristic features of evidence, as well as the lack of large case series with a long-term follow-up, recommends caution regarding therapeutic conclusions [38].

\section{Metastases to the breast with papillary architecture}

Metastases from ovarian carcinomas, mucinous tumors of the GI tract, particularly the pancreas, renal cell carcinomas, lung adenocarcinoma, papillary thyroid carcinoma, and prostate ductal adenocarcinoma may show a papillary architecture and mimic a primary papillary neoplasm of the breast [44]. A case of metastatic gastrinoma mimicking SPC was reported [12]. Immunohistochemistry is helpful for differential diagnosis and may be crucial for certain cases.

\section{Micropapillary DCIS}

Micropapillary DCIS (MP DCIS) is a pattern of DCIS characterized by the formation of micropapillae. In contrast to papillae, micropapillae lack a fibrovascular core. MP DCIS is frequently associated with "snake skin-like" microcalcification [81]. High rate of recurrence following breast conserving surgery has been reported [14].

MP DCIS is composed of low-grade neoplastic cells involving usually small and mid-sized ducts (Fig. 11). MP DCIS may occur together with other patterns of DCIS (e.g., cribriform, solid). Immunohistochemistry with high molecular weight keratins (CK5 or 14) is useful to distinguish MP DCIS from UDH with micropapillary pattern.

\section{Invasive micropapillary carcinoma}

Invasive micropapillary carcinoma (IMPC) is characterized by clusters of cells within clear spaces showing an inside-out 
Fig. 10 Mucinous cystadenocarcinoma consisting of cysts filled with abundant mucin (A). The delicate fibrous septa are covered by eosinophilic tumor cells with floating cellular morules on top $(\mathbf{C})$. The tumor cells may show abundant mucin production (D)
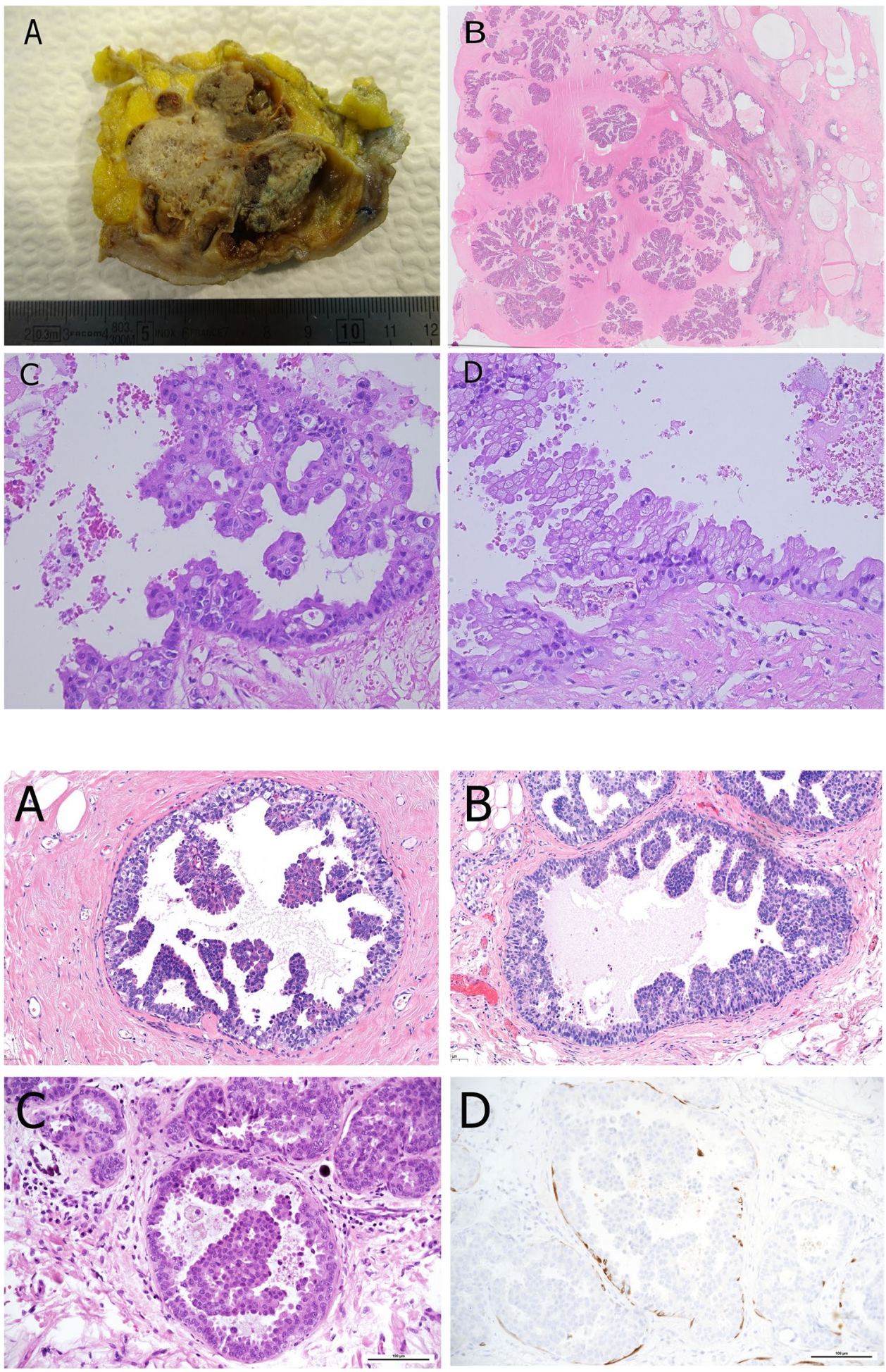

Fig. 11 Micropapillary and papillary DCIS in a small duct (A) adjacent to invasive papillary carcinoma (not shown). Pure micropapillary DCIS is characterized by micropapillary projections lacking fibrovascular cores and typical triangular architecture observed in micropapillary hyperplasia (B, C). Immunohistochemistry for CK5 shows the lack of basally differentiated cells (D) pattern. IMPC presents as palpable lesion with variable imaging features including frequent microcalcifications, all highly suspicious of malignancy $[3,6,16]$. With a prevalence of $<2 \%$, pure IMPC is about four times rarer than mixed IMPC with NST [54]. Relatively small solid nests or rings of tumor cells are present in empty spaces because of detachment from the surrounding stroma mimicking retraction clefts, invasion in adipose tissue or in lymphatic vessels (Fig. 12) [2]. The apical pole is usually oriented towards the empty spaces displaying an"inside-out" or reversed polarity pattern, which can be highlighted by EMA or MUC1 immunohistochemistry [54]. Most IMPC are ER- and/or PR-positive. The reversed polarity is 
Fig. 12 Invasive micropapillary carcinoma characterized by an "inside-out" growth pattern (A) highlighted by EMA immunoreactivity (B). In contrast, EMA is negative in invasive NST carcinomas with retraction clefts $(\mathbf{C}, \mathbf{D})$
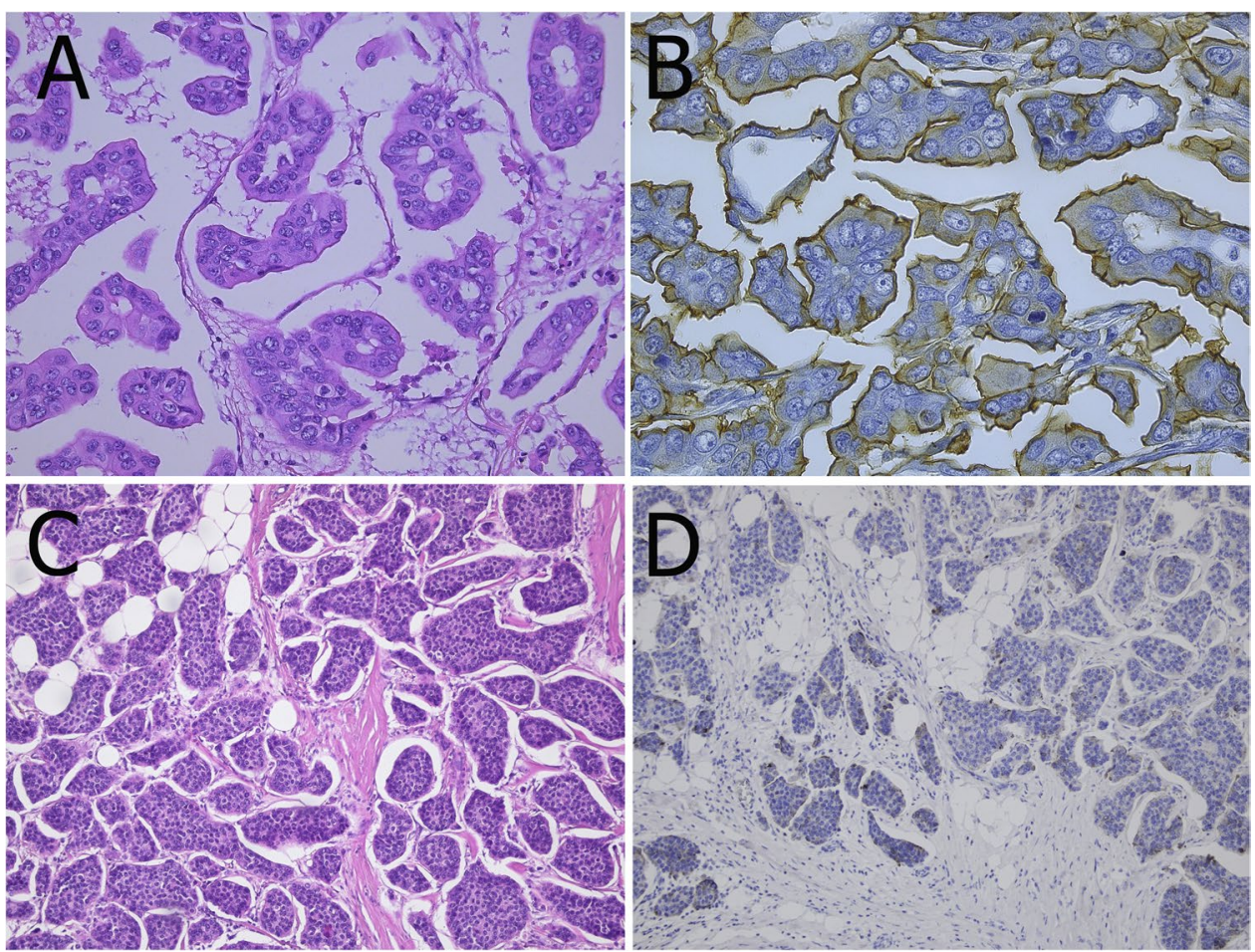

also reflected by the peculiar incomplete U-shaped basolateral membrane staining pattern for HER2, which challenges the current guidelines for the interpretation of HER 2 immunohistochemistry [95]. Amplification of HER2 is seen in 10-30\% of IMPC, while a triple negative phenotype is rare. Despite higher frequency of lymph node metastasis, higher tumor grade, and more frequent lymph vascular invasion compared to NST carcinomas, pure IMPC does not show worse prognosis [16]. A higher level of stromal tumor infiltrating lymphocytes (TILs) seems to be associated with features of dismal prognosis when compared to IMPC with low TILs, being consistent with the predominant luminal phenotype of IMPC [22]. Immunohistochemistry for GATA3, WT1, and PAX8 is useful to exclude metastasis from ovarian serous carcinoma.

IMPC does not show pathognomonic mutations or translocations but distinctive complex patterns of copy number
Fig. 13 Secretory carcinoma with papillary architecture in a core needle biopsy (A). Solid areas $(\mathbf{B})$ in transition to microcystic areas with presence of intraluminal eosinophilic secretion $(\mathbf{C})$ and prominent papillary architecture $(\mathbf{D})$ are typical cytoarchitectural features

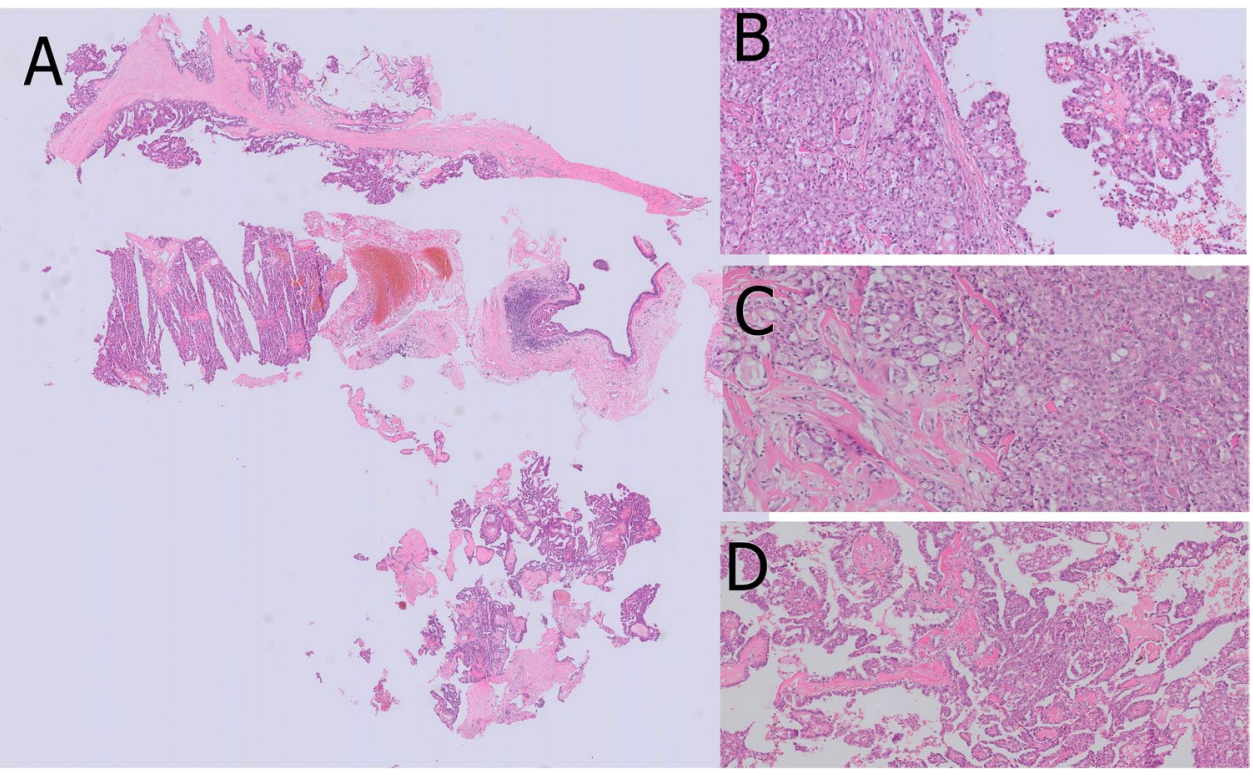


Fig. 14 Adenomyoepithelioma with partial papillary growth pattern showing multinodular architecture with thick fibrovascular septa (A) and presence of expansive nodules of myoepithelial cells (*). The myoepithelial nodules show a mixture of glandular adenosis-like and spindle cell growth patterns $(\mathbf{B})$ Proliferation of myoepithelial cells is confirmed by CK14 (C), calponin (D), and p63 immunostaining $(\mathbf{E})$

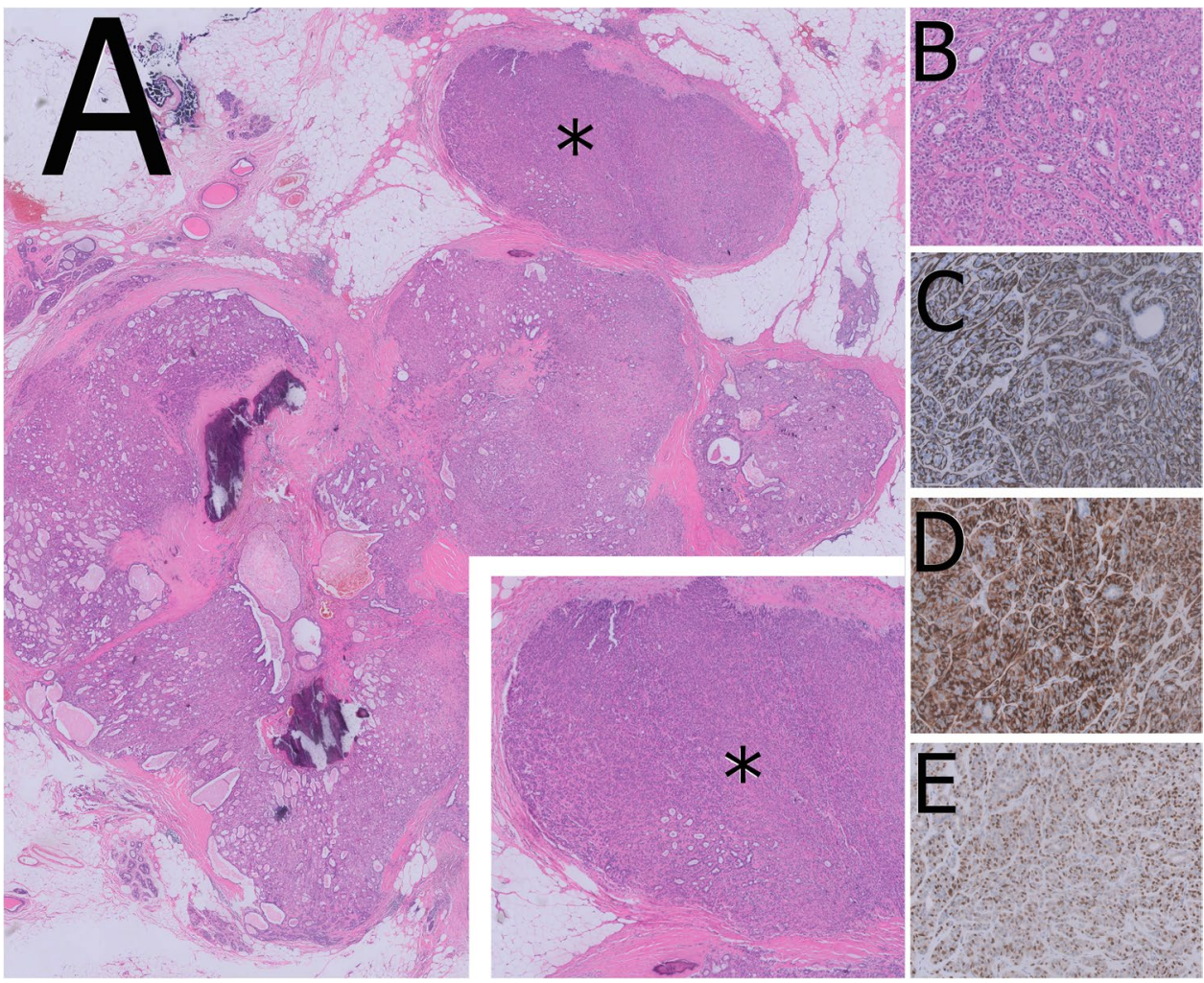

alterations as compared to NST carcinomas, such as $16 \mathrm{q}$ losses and 8q, 17q, and 20q gains [55]. Amplification of $M Y C$ (8q24), CCNDI, and FGFRl genes is frequent [56]. Mutations are present in the MAPK pathway and in TP53 and PIK3CA [63]. Sporadic reports also describe mutations and deregulations in genes involved in cell polarity, shape, migration, and ciliogenesis [32].

\section{Secretory breast carcinoma with papillary growth pattern}

Secretory breast carcinoma (SBC) is exceedingly rare and characterized by a pathognomonic recurrent $t(12 ; 15)$ (p13;q25) translocation, which results in the chimeric fusion gene ETV6-NTRK3 [84]. SBC is mostly observed in postmenopausal women although it can occur at any age and also in males [36]. SBC presents as a slowly growing mass sharing radiological features with benign lesions like papillomas
Fig. 15 Intraductal papilloma with myoepithelial hyperplasia showing an area with increased cellularity (asterisk) (A) characterized by expansion of myoepithelial cells (B). The retained myoepithelial layer and the expansion of the myoepithelial compartment is highlighted by p63 (C) and CD10 (D) immunoreactivity

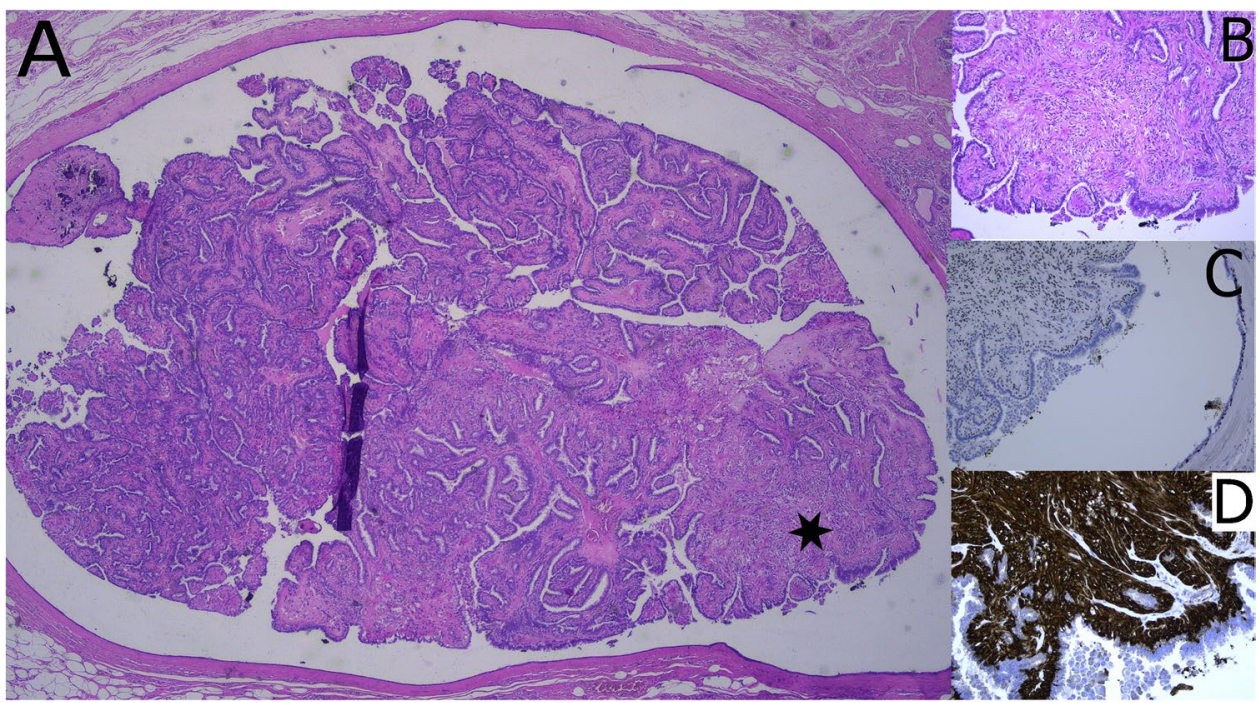


[87]. A predominant papillary pattern may be observed on occasion resulting in a challenging diagnosis on CNB [80]. SBC is composed of a heterogeneous cellular component including cells with amphophilic cytoplasm, apocrine aspect or a "bubbly aspect" due to abundant intracytoplasmic secretions (Fig. 13). Eosinophilic extracellular material positive for PAS, mucicarmine, and Alcian blue is consistently present. SBC usually shows a triple negative phenotype, but low ER expression and an ER - /PR + phenotype have been observed. S100 and mammaglobin are usually positive; expression of GCDFP-15 has been debated [18, 37, 47]. Pan-TRK immunohistochemistry has been suggested as a useful tool to confirm SBC diagnosis, or may be used for the selection of patients eligible for NTRK inhibitor therapy in the metastatic setting $[79,89]$. The clinical course of SBC is indolent compared to IBC-NST; however, metastatic cases have recently been described $[34,37]$.

\section{Adenomyoepithelioma with papillary growth pattern}

Adenomyoepithelioma (AME) of the breast is characterized by an epithelial-myoepithelial phenotype with heterogeneous architecture including a predominant papillary pattern [29]. AME is very rare and occurs mainly in post-menopausal women. Radiologically, it displays lobulated dense masses with often indistinct margins [57, 67]. AME diagnosis should be restricted to cases showing a biphasic cytology with prevalent expansion and proliferation of the myoepithelial component (Fig. 14). The distinction of AME from intraductal papilloma with myoepithelial hyperplasia is important due to the different biological behavior. While myoepithelial hyperplasia is generally focal in benign papillary lesions (Fig. 15), it is diffusely expanded in papillary AME [33]. AME can be ER-positive or -negative and is characterized by a different genomic landscape (e.g., HRAS Q61 hotspot mutations in ER-negative AME) [30, 31]. The current WHO classification distinguishes between AME and malignant AME [27, 28]. However, the identification of atypical and malignant features is extremely challenging and remains a source of debate. Recently, the following detailed definitions for the distinction between AME and malignant AME were published [70]. Malignant AME in situ includes lesions with a classical AME architecture in which the epithelial component shows features of DCIS. The atypical cells show a cribriform or solid growth pattern with a well-defined margin or evidence of development within an intraductal-like structure. A peripheral myoepithelial cell layer at the epithelial stroma interface is typically seen. Malignant AME invasive (synonym: invasive adenomyoepithelial carcinoma) displays a dominant AME architecture but

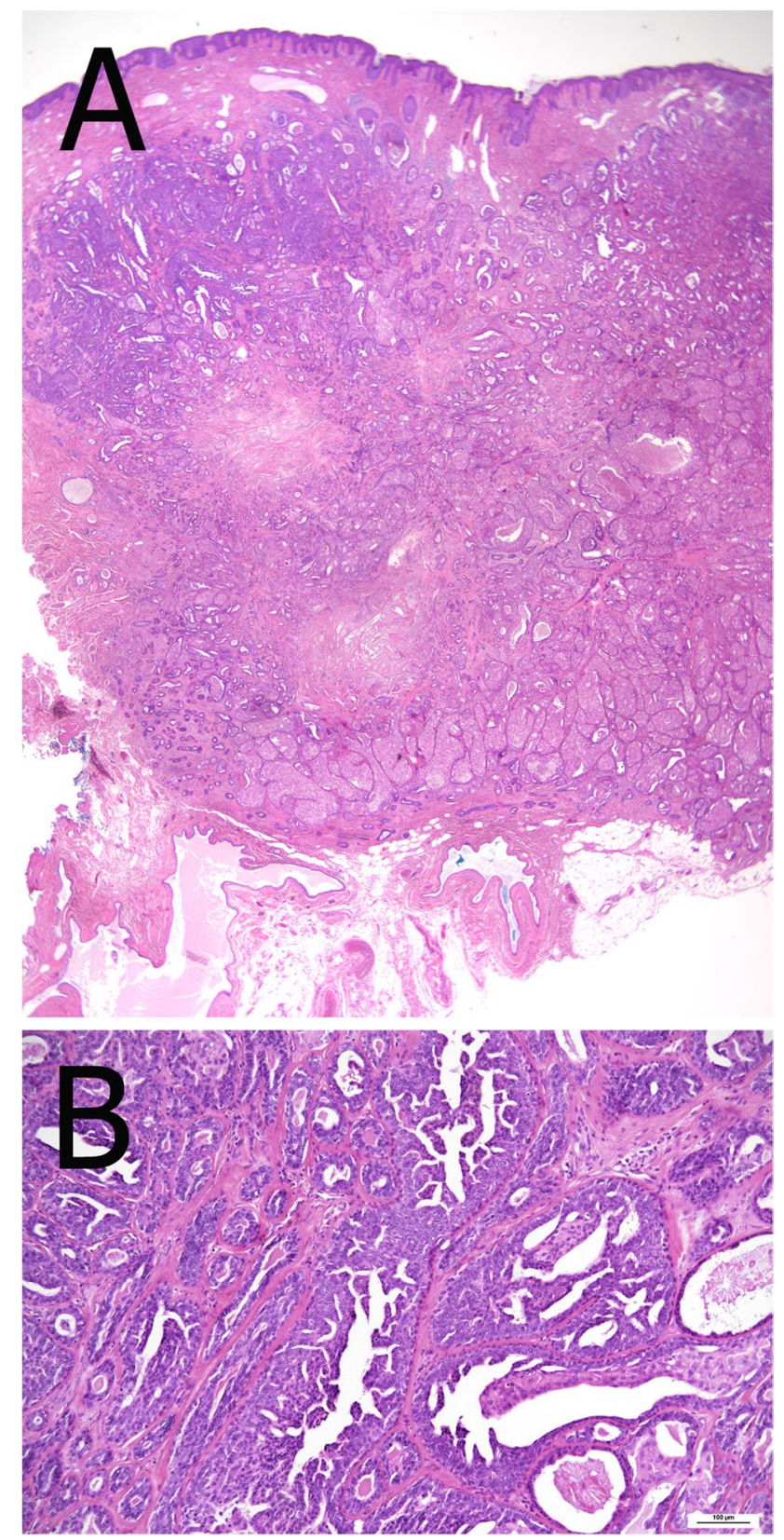

Fig. 16 Nipple adenoma presenting as a mass at the dermo-epidermal junction with a large duct at the periphery (A). Focally, usual ductal hyperplasia with papillary architecture is evident $(\mathbf{B})$

also has features sufficient for a diagnosis of malignancy including cytological atypia, increased mitotic activity, and necrosis associated with frankly invasive foci and an accompanying stromal response. The malignancy in these tumors can affect the luminal epithelial or the myoepithelial components or both [70]. 


\section{Nipple adenoma}

Nipple adenoma (NA) is a benign tumor originally described as florid papillomatosis of the nipple [78]. NA occurs both in females and males with a wide age range (5 months to 89 years). Clinically, it may resemble Paget's disease of the nipple. The dermo-epidermal junction is regarded as the site of origin. Involvement of the subareolar ducts with a general papillary aspect is a common feature. Histologically, a mixture of adenosis, papillary hyperplasia, and usual ductal hyperplasia is observed, frequently associated with squamous or apocrine metaplasia (Fig. 16). The presence of sclerosis may result in a pseudo-invasive growth pattern [78]. Immunohistochemistry using CK 5, ER, and myoepithelial markers helps in the differential diagnosis with DCIS or invasive carcinoma. The association with DCIS and invasive carcinoma has been rarely reported $[1,23,91]$. Mutations in PIK3CA are frequent; $K-R A S$ and $B R A F$ mutations may also occur [48]. Incomplete resection is associated with recurrence.

\section{Non-neoplastic lesions with papillary structures}

A variety of non-neoplastic lesions may show a papillary or micropapillary pattern. Among those, juvenile papillomatosis, florid gynecomastia with micropapillae-like intraductal epithelial proliferation, papillary apocrine metaplasia and UDH with papillary pattern (papillary intraductal hyperplasia) are encountered. These lesions are beyond the scope of this review and are not further discussed in detail.

\section{Conclusion}

Papillary breast lesions form a heterogeneous group of neoplastic and non-neoplastic diseases of which some may cause diagnostic difficulties. Immunohistochemistry, particularly for myoepithelial markers, is helpful for differential diagnosis. Triple negative carcinomas with papillary architecture are rare and considered non-aggressive TNBC. Due to increasing experience and endeavor to avoid overtreatment, the clinical management of benign intraductal papilloma seems to become more conservative, while keeping strict criteria of eligibility for nonoperative treatment. In this respect, increasing knowledge about molecular genetic alterations will help to optimize therapeutic strategies.

Acknowledgements Dr. Floris is recipient of a post-doctoral mandate from the Klinsche Onderzoek en OpleidingsRaad (KOOR) of the
University Hospitals Leuven. Dr. Kulka and Dr. Madaras are grateful to Adrián Pesti for scanning the illustrative slides.

Author contribution Conception and design: J. Kulka with support of all authors; drafting of the article: J. Kulka; figures: all authors; critical revision and further development of the manuscript: all authors.

Funding Open access funding provided by Semmelweis University.

\section{Declarations}

Ethics approval The work was carried out according to ethical standards.

Conflict of interest Dr. Lax reports personal fees from Roche, AstraZeneca, Novartis, and Biogena outside the submitted work. All other authors declare no conflict of interest.

Open Access This article is licensed under a Creative Commons Attribution 4.0 International License, which permits use, sharing, adaptation, distribution and reproduction in any medium or format, as long as you give appropriate credit to the original author(s) and the source, provide a link to the Creative Commons licence, and indicate if changes were made. The images or other third party material in this article are included in the article's Creative Commons licence, unless indicated otherwise in a credit line to the material. If material is not included in the article's Creative Commons licence and your intended use is not permitted by statutory regulation or exceeds the permitted use, you will need to obtain permission directly from the copyright holder. To view a copy of this licence, visit http://creativecommons.org/licenses/by/4.0/.

\section{References}

1. Abdulwaasey M, Tariq MU, Minhas K, Kayani N (2020) Invasive breast carcinoma arising in a nipple adenoma after 15 years: report of a rare case and literature review. Cureus 12:e8586. https://doi. org $/ 10.7759 /$ cureus. 8586

2. Acs G, Khakpour N, Kiluk J, Lee MC, Laronga C (2015) The presence of extensive retraction clefts in invasive breast carcinomas correlates with lymphatic invasion and nodal metastasis and predicts poor outcome: a prospective validation study of 2742 consecutive cases. Am J Surg Pathol 39:325-337. https://doi.org/ 10.1097/PAS.0000000000000339

3. Adrada B, Arribas E, Gilcrease M, Yang WT (2009) Invasive micropapillary carcinoma of the breast: mammographic, sonographic, and MRI features. AJR Am J Roentgenol 193:W58-63. https://doi.org/10.2214/AJR.08.1537

4. Agoumi M, Giambattista J, Hayes MM (2016) Practical considerations in breast papillary lesions: a review of the literature. Arch Pathol Lab Med 140:770-790. https://doi.org/10.5858/arpa.2015-0525-RA

5. Alsadoun N, MacGrogan G, Truntzer C, Lacroix-Triki M, Bedgedjian I, Koeb MH, El Alam E, Medioni D, Parent M, Wuithier P, Robert I, Boidot R, Arnould L (2018) Solid papillary carcinoma with reverse polarity of the breast harbors specific morphologic, immunohistochemical and molecular profile in comparison with other benign or malignant papillary lesions of the breast: a comparative study of 9 additional cases. Mod Pathol 31:1367-1380. https://doi.org/10.1038/s41379-018-0047-1

6. Alsharif S, Daghistani R, Kamberoglu EA, Omeroglu A, Meterissian S, Mesurolle B (2014) Mammographic, sonographic and MR 
imaging features of invasive micropapillary breast cancer. Eur J Radiol 83:1375-1380. https://doi.org/10.1016/j.ejrad.2014.05.003

7. ASBrS (2018) The American Society of Breast Surgeons Consensus Guideline on Concordance Assessment of Image-Guided Breast Biopsies and Management of Borderline or High-Risk Lesions. https://www.breastsurgeons.org/docs/statements/Conse nsus-Guideline-on-Concordance-Assessment-of-Image-GuidedBreast-Biopsies.pdf

8. Bianchi S, Bendinelli B, Saladino V, Vezzosi V, Brancato B, Nori J, Palli D (2015) Non-malignant breast papillary lesions b3 diagnosed on ultrasound--guided 14-gauge needle core biopsy: analysis of 114 cases from a single institution and review of the literature. Pathol Oncol Res 21:535-546. https://doi.org/10.1007/ s12253-014-9882-7

9. Boecker W, Buerger H, Schmitz K, Ellis IA, van Diest PJ, Sinn HP, Geradts J, Diallo R, Poremba C, Herbst H (2001) Ductal epithelial proliferations of the breast: a biological continuum? Comparative genomic hybridization and high-molecular-weight cytokeratin expression patterns J Pathol 195:415-421. https://doi. org/10.1002/path.982

10. Brogi E, Horii R, MacGrogan G, Rakha EA, Troxell ML, Tse M (2019) Papillary neoplasms: introduction. In: WHO classification of tumours editorial board. Breast Tumours, Lyon (France), International Agency for Research on Cancer (WHO classification of tumours series, 5th edn, vol 2), pp 49-52

11. Brogi E, Krystel-Whittemore M (2021) Papillary neoplasms of the breast including upgrade rates and management of intraductal papilloma without atypia diagnosed at core needle biopsy. Mod Pathol 34:78-93. https://doi.org/10.1038/s41379-020-00706-5

12. Burt M, Madan R, Fan F (2016) Metastatic gastrinoma in the breast mimicking primary solid papillary carcinoma. Hum Pathol 56:143-146. https://doi.org/10.1016/j.humpath.2016. 05.024

13. Calhoun BC, Collins LC (2016) Recommendations for excision following core needle biopsy of the breast: a contemporary evaluation of the literature. Histopathology 68:138-151. https:// doi.org/10.1111/his.12852

14. Castellano I, Marchio C, Tomatis M, Ponti A, Casella D, Bianchi S, Vezzosi V, Arisio R, Pietribiasi F, Frigerio A, Mano MP, Ricardi U, Allia E, Accortanzo V, Durando A, Bussolati G, Tot T, Sapino A (2010) Micropapillary ductal carcinoma in situ of the breast: an inter-institutional study. Mod Pathol 23:260-269. https://doi.org/10.1038/modpathol.2009.169

15. Chang JM, Han W, Moon WK, Cho N, Noh DY, Park IA, Jung EJ (2011) Papillary lesions initially diagnosed at ultrasoundguided vacuum-assisted breast biopsy: rate of malignancy based on subsequent surgical excision. Ann Surg Oncol 18:25062514. https://doi.org/10.1245/s10434-011-1617-3

16. Chen AC, Paulino AC, Schwartz MR, Rodriguez AA, Bass BL, Chang JC, Teh BS (2014) Population-based comparison of prognostic factors in invasive micropapillary and invasive ductal carcinoma of the breast. Br J Cancer 111:619-622. https://doi. org/10.1038/bjc.2014.301

17. Christgen M, Bartels S, van Luttikhuizen JL, Schieck M, Pertschy S, Kundu S, Lehmann U, Sander B, Pelz E, Langer F, Schlegelberger B, Steinemann D, Kreipe H (2017) Subclonal analysis in a lobular breast cancer with classical and solid growth pattern mimicking a solid-papillary carcinoma J Pathol. Clin Res 3:191-202. https://doi.org/10.1002/cjp2.76

18. Cimino-Mathews A (2021) Novel uses of immunohistochemistry in breast pathology: interpretation and pitfalls. Mod Pathol 34:62-77. https://doi.org/10.1038/s41379-020-00697-3

19. Collins LC, Carlo VP, Hwang H, Barry TS, Gown AM, Schnitt SJ (2006) Intracystic papillary carcinomas of the breast: a reevaluation using a panel of myoepithelial cell markers. Am J
Surg Pathol 30:1002-1007. https://doi.org/10.1097/00000478200608000-00011

20. Collins LC, Schnitt SJ (2008) Papillary lesions of the breast: selected diagnostic and management issues. Histopathology 52:20-29. https://doi.org/10.1111/j.1365-2559.2007.02898.x

21. Cserni G (2012) Benign apocrine papillary lesions of the breast lacking or virtually lacking myoepithelial cells-potential pitfalls in diagnosing malignancy. APMIS 120:249-252. https://doi.org/ 10.1111/j.1600-0463.2011.02840.x

22. Deman F, Punie K, Laenen A, Neven P, Oldenburger E, Smeets A, Nevelsteen I, Van Ongeval C, Baten A, Faes T, Christiaens M, Janssen H, Weltens C, Desmedt C, Wildiers H, Floris G (2020) Assessment of stromal tumor infiltrating lymphocytes and immunohistochemical features in invasive micropapillary breast carcinoma with long-term outcomes. Breast Cancer Res Treat 184:985-998. https://doi.org/10.1007/ s10549-020-05913-x

23. Di Bonito M, Cantile M, Collina F, D'Aiuto M, Liguori RDEC, Botti G (2014) Adenoma of the nipple: a clinicopathological report of 13 cases. Oncol Lett 7:1839-1842. https://doi.org/10. 3892/ol.2014.2000

24. Di Cristofano C, Mrad K, Zavaglia K, Bertacca G, Aretini P, Cipollini G, Bevilacqua G, Ben Romdhane K, Cavazzana A (2005) Papillary lesions of the breast: a molecular progression? Breast Cancer Res Treat 90:71-76. https://doi.org/10.1007/ s10549-004-3003-3

25. Duprez R, Wilkerson PM, Lacroix-Triki M, Lambros MB, MacKay A, A'Hern R, Gauthier A, Pawar V, Colombo PE, Daley F, Natrajan R, Ward E, MacGrogan G, Arbion F, Michenet P, Weigelt B, Vincent-Salomon A, Reis-Filho JS (2012) Immunophenotypic and genomic characterization of papillary carcinomas of the breast. J Pathol 226:427-441. https://doi.org/10. 1002/path.3032

26. Foschini MP, Asioli S, Foreid S, Cserni G, Ellis IO, Eusebi V, Rosai J (2017) Solid papillary breast carcinomas resembling the tall cell variant of papillary thyroid neoplasms: a unique invasive tumor with indolent behavior. Am J Surg Pathol 41:887-895. https://doi.org/10.1097/PAS.0000000000000853

27. Foschini MP, Geyer FC, Hayes MM, Marchio C, Nishimura R (2019) Adenomyoepithelioma. In: WHO classification of tumours editorial board. Breast Tumours, Lyon (France), International Agency for Research on Cancer (WHO classification of tumours series, 5th edn, vol 2), pp 43-45

28. Foschini MP, Geyer FC, Hayes MM, Marchio C, Nishimura R (2019) Malignant adenomyoepithelioma. In: WHO classification of tumours editorial board. Breast Tumours, Lyon (France), International Agency for Research on Cancer (WHO classification of tumours series, 5th edn, vol 2), pp 46-48

29. Foschini MP, Morandi L, Asioli S, Giove G, Corradini AG, Eusebi V (2017) The morphological spectrum of salivary gland type tumours of the breast. Pathology 49:215-227. https://doi.org/10. 1016/j.pathol.2016.10.011

30. Geyer FC, Li A, Papanastasiou AD, Smith A, Selenica P, Burke KA, Edelweiss M, Wen HC, Piscuoglio S, Schultheis AM, Martelotto LG, Pareja F, Kumar R, Brandes A, Fan D, Basili T, Da Cruz Paula A, Lozada JR, Blecua P, Muenst S, Jungbluth AA, Foschini MP, Wen HY, Brogi E, Palazzo J, Rubin BP, Ng CKY, Norton L, Varga Z, Ellis IO, Rakha EA, Chandarlapaty S, Weigelt Reis-Filho BJS (2018) Recurrent hotspot mutations in HRAS Q61 and PI3K-AKT pathway genes as drivers of breast adenomyoepitheliomas. Nat Commun 9:1816. https://doi.org/10.1038/ s41467-018-04128-5

31. Ginter PS, McIntire PJ, Kurtis B, Mirabelli S, Motanagh S, Hoda S, Elemento O, Shin SJ, Mosquera JM (2020) Adenomyoepithelial tumors of the breast: molecular underpinnings of a 
rare entity. Mod Pathol 33:1764-1772. https://doi.org/10.1038/ s41379-020-0552-x

32. Gruel N, Benhamo V, Bhalshankar J, Popova T, Freneaux P, Arnould L, Mariani O, Stern MH, Raynal V, Sastre-Garau X, Rouzier R, Delattre O, Vincent-Salomon A (2014) Polarity gene alterations in pure invasive micropapillary carcinomas of the breast. Breast Cancer Res 16:R46. https://doi.org/10.1186/bcr3653

33. Hayes MM (2011) Adenomyoepithelioma of the breast: a review stressing its propensity for malignant transformation. J Clin Pathol 64:477-484. https://doi.org/10.1136/jcp.2010.087718

34. Hoda RS, Brogi E, Pareja F, Nanjangud G, Murray MP, Weigelt B, Reis-Filho JS, Wen HY (2019) Secretory carcinoma of the breast: clinicopathologic profile of 14 cases emphasising distant metastatic potential. Histopathology 75:213-224. https://doi.org/ 10.1111/his. 13879

35. Corben AD, Brogi E (2014) Mucinous carcinoma. In: Hoda SA, Brogi E, Koerner FC, Rosen PP (eds) Rosen's breast pathology, 4th edn. Lippincott Williams \& Wilkins, a Wolters Kluwer business, Philadelphia, pp 621-622

36. Horowitz DP, Sharma CS, Connolly E, Gidea-Addeo D, Deutsch I (2012) Secretory carcinoma of the breast: results from the survival, epidemiology and end results database. Breast 21:350-353. https://doi.org/10.1016/j.breast.2012.02.013

37. Jacob JD, Hodge C, Franko J, Pezzi CM, Goldman CD, Klimberg VS (2016) Rare breast cancer: 246 invasive secretory carcinomas from the National Cancer Data Base. J Surg Oncol 113:721-725. https://doi.org/10.1002/jso.24241

38. Jain E, Kumar A, Jain R, Sharma S (2021) Primary mucinous cystadenocarcinoma of the breast: a rare case report with review of literature. Int J Surg Pathol 29:740-746. https://doi.org/10.1177/ 1066896921991650

39. Jorns JM (2016) Papillary lesions of the breast: a practical approach to diagnosis. Arch Pathol Lab Med 140:1052-1059. https://doi.org/10.5858/arpa.2016-0219-RA

40. Kader T, Elder K, Zethoven M, Semple T, Hill P, Goode DL, Thio N, Cheasley D, Rowley SM, Byrne DJ, Pang JM, Miligy IM, Green AR, Rakha EA, Fox SB, Mann GB, Campbell IG, Gorringe KL (2020) The genetic architecture of breast papillary lesions as a predictor of progression to carcinoma NPJ. Breast Cancer 6:9. https://doi.org/10.1038/s41523-020-0150-6

41. Khoury T, Hu Q, Liu S, Wang J (2014) Intracystic papillary carcinoma of breast: interrelationship with in situ and invasive carcinoma and a proposal of pathogenesis: array comparative genomic hybridization study of 14 cases. Mod Pathol 27:194-203. https:// doi.org/10.1038/modpathol.2013.136

42. Koenig C, Tavassoli FA (1998) Mucinous cystadenocarcinoma of the breast. Am J Surg Pathol 22:698-703. https://doi.org/10.1097/ 00000478-199806000-00006

43. Kuehner G, Darbinian J, Habel L, Axelsson K, Butler S, Chang S, Chen R, Fehrenbacher L (2019) Benign papillary breast mass lesions: favorable outcomes with surgical excision or imaging surveillance. Ann Surg Oncol 26:1695-1703. https://doi.org/10. 1245/s10434-019-07180-7

44. Kulka J, Varga Z (2019) Metastases to the breast. In: WHO classification of tumours editorial board. Breast Tumours, Lyon (France), International Agency for Research on Cancer (WHO classification of tumours series, 5th edn, vol 2), pp 262-265

45. Lavoue V, Fritel X, Antoine M, Beltjens F, Bendifallah S, BoisserieLacroix M, Boulanger L, Canlorbe G, Catteau-Jonard S, ChabbertBuffet N, Chamming's F, Chereau E, Chopier J, Coutant C, Demetz J, Guilhen N, Fauvet R, Kerdraon O, Laas E, Legendre G, Mathelin C, Nadeau C, Naggara IT, Ngo C, Ouldamer L, Rafii A, Roedlich
MN, Seror J, Seror JY, Touboul C, Uzan C, E Darai French College of G, Obstetricians (2016) Clinical practice guidelines from the French College of Gynecologists and Obstetricians (CNGOF): benign breast tumors - short text. Eur J Obstet Gynecol Reprod Biol 200:16-23. https://doi.org/10.1016/j.ejogrb.2016.02.017

46. Lewis JT, Hartmann LC, Vierkant RA, Maloney SD, Shane Pankratz V, Allers TM, Frost MH, Visscher DW (2006) An analysis of breast cancer risk in women with single, multiple, and atypical papilloma. Am J Surg Pathol 30:665-672. https://doi.org/10.1097/ 00000478-200606000-00001

47. Li D, Xiao X, Yang W, Shui R, Tu X, Lu H, Shi D (2012) Secretory breast carcinoma: a clinicopathological and immunophenotypic study of 15 cases with a review of the literature. Mod Pathol 25:567-575. https://doi.org/10.1038/modpathol.2011.190

48. Liau JY, Lee YH, Tsai JH, Yuan CT, Chu CY, Hong JB, Sheen YS (2017) Frequent PIK3CA activating mutations in nipple adenomas. Histopathology 70:195-202. https://doi.org/10.1111/his. 13043

49. Lin LH, Ozerdem U, Cotzia P, Lee J, Chun J, Schnabel F, Darvishian F (2021) Upgrade rate of intraductal papilloma diagnosed on core needle biopsy in a single institution. Hum Pathol 110:43-49. https://doi.org/10.1016/j.humpath.2020.10.012

50. Mac Grogan G, Collins LC, Lerwill M, Rakha E, Tan BY (2019) Encapsulated papillary carcinoma. In: WHO classification of tumours editorial board. Breast Tumours, Lyon (France), International Agency for Research on Cancer (WHO classification of tumours series, 5th edn, vol 2), pp 60-62

51. Mac Grogan G, Collins LC, Lerwill M, Rakha E, Tan BY (2019) Solid papillary carcinoma (in situ and invasive). In: WHO classification of tumours editorial board. Breast Tumours, Lyon (France), International Agency for Research on Cancer (WHO classification of tumours series, 5th edn, vol 2), pp 63-65

52. MacColl C, Salehi A, Parpia S, Hodgson N, Ramonas M, Williams P (2019) Benign breast papillary lesions diagnosed on core biopsy: upgrade rate and risk factors associated with malignancy on surgical excision. Virchows Arch 475:701-707. https://doi.org/ 10.1007/s00428-019-02626-5

53. Maluf HM, Koerner FC (1995) Solid papillary carcinoma of the breast. A form of intraductal carcinoma with endocrine differentiation frequently associated with mucinous carcinoma Am J Surg Pathol 19:1237-1244. https://doi.org/10.1097/00000478-19951 1000-00003

54. Marchio C, Horlings HM, Vincent-Salomon A (2019) Invasive micropapillary carcinoma. In: WHO classification of tumours editorial board. Breast Tumours, Lyon (France), International Agency for Research on Cancer (WHO classification of tumours series, 5th edn, vol 2), pp 128-130

55. Marchio C, Iravani M, Natrajan R, Lambros MB, Geyer FC, Savage K, Parry S, Tamber N, Fenwick K, Mackay A, Schmitt FC, Bussolati G, Ellis I, Ashworth A, Sapino A, Reis-Filho JS (2009) Mixed micropapillary-ductal carcinomas of the breast: a genomic and immunohistochemical analysis of morphologically distinct components. J Pathol 218:301-315. https://doi.org/10.1002/path.2572

56. Marchio C, Iravani M, Natrajan R, Lambros MB, Savage K, Tamber N, Fenwick K, Mackay A, Senetta R, Di Palma S, Schmitt FC, Bussolati G, Ellis LO, Ashworth A, Sapino A, Reis-Filho JS (2008) Genomic and immunophenotypical characterization of pure micropapillary carcinomas of the breast. J Pathol 215:398410. https://doi.org/10.1002/path.2368

57. Moritz AW, Wiedenhoefer JF, Profit AP, Jagirdar J (2016) Breast adenomyoepithelioma and adenomyoepithelioma with carcinoma (malignant adenomyoepithelioma) with associated breast 
malignancies: A case series emphasizing histologic, radiologic, and clinical correlation. Breast 29:132-139. https://doi.org/10. 1016/j.breast.2016.07.018

58. Moseley T, Desai B, Whitman GJ, Robinson EK, Saunders T, Gonzalez A, He H (2021) Benign breast intraductal papillomas without atypia at core needle biopsies: is surgical excision necessary? Ann Surg Oncol 28:1347-1355. https://doi.org/10.1245/ s10434-020-09061-w

59. Motanagh SA, Muller KE (2020) Invasive lobular carcinoma with papillary features: a newly described variant that poses a difficult histologic differential diagnosis. Breast J 26:1231-1233. https:// doi.org/10.1111/tbj.13784

60. Moynihan A, Quinn EM, Smith CS, Stokes M, Kell M, Barry JM, Walsh SM (2020) Benign breast papilloma: is surgical excision necessary? Breast J 26:705-710. https://doi.org/10.1111/tbj.13642

61. Mulligan AM, O'Malley FP (2007) Metastatic potential of encapsulated (intracystic) papillary carcinoma of the breast: a report of 2 cases with axillary lymph node micrometastases. Int J Surg Pathol 15:143-147. https://doi.org/10.1177/1066896906299119

62. Nakhlis F, Baker GM, Pilewskie M, Gelman R, Calvillo KZ, Ludwig K, McAuliffe PF, Willey S, Rosenberger LH, Parker C, Gallagher K, Jacobs L, Feldman S, Lange P, DeSantis SD, Schnitt SJ, King TA (2021) The incidence of adjacent synchronous invasive carcinoma and/or ductal carcinoma in situ in patients with intraductal papilloma without atypia on core biopsy: results from a prospective multi-institutional registry (TBCRC 034). Ann Surg Oncol 28:2573-2578. https://doi.org/10.1245/ s10434-020-09215-w

63. Natrajan R, Wilkerson PM, Marchio C, Piscuoglio S, Ng CK, Wai P, Lambros MB, Samartzis EP, Dedes KJ, Frankum J, Bajrami I, Kopec A, Mackay A, A’Hern R, Fenwick K, Kozarewa I, Hakas J, Mitsopoulos C, Hardisson D, Lord CJ, Kumar-Sinha C, Ashworth A, Weigelt B, Sapino A, Chinnaiyan AM, Maher CA, Reis-Filho JS (2014) Characterization of the genomic features and expressed fusion genes in micropapillary carcinomas of the breast. J Pathol 232:553-565. https://doi.org/10.1002/path.4325

64. Ni YB, Tse GM (2016) Pathological criteria and practical issues in papillary lesions of the breast - a review. Histopathology 68:2232. https://doi.org/10.1111/his.12866

65. Otsuki Y, Yamada M, Shimizu S, Suwa K, Yoshida M, Tanioka F, Ogawa H, Nasuno H, Serizawa A, Kobayashi H (2007) Solidpapillary carcinoma of the breast: clinicopathological study of 20 cases. Pathol Int 57:421-429. https://doi.org/10.1111/j.14401827.2007.02118.x

66. Pareja F, Corben AD, Brennan SB, Murray MP, Bowser ZL, Jakate K, Sebastiano C, Morrow M, Morris EA, Brogi E (2016) Breast intraductal papillomas without atypia in radiologic-pathologic concordant core-needle biopsies: rate of upgrade to carcinoma at excision. Cancer 122:2819-2827. https://doi.org/10.1002/cncr.30118

67. Parikh P, Jameel Z, Falcon S, Rosa M, Kiluk J, Hoover S, Soliman H, Ataya D (2021) Adenomyoepithelioma of the breast: case series and literature review. Clin Imaging 75:157-164. https://doi.org/10. 1016/j.clinimag.2021.02.002

68. Piscuoglio S, Ng CK, Martelotto LG, Eberle CA, Cowell CF, Natrajan R, Bidard FC, De Mattos-Arruda L, Wilkerson PM, Mariani O, Vincent-Salomon A, Weigelt B, Reis-Filho JS (2014) Integrative genomic and transcriptomic characterization of papillary carcinomas of the breast. Mol Oncol 8:1588-1602. https://doi.org/10.1016/j. molonc.2014.06.011

69. Rageth CJ, O’Flynn EAM, Pinker K, Kubik-Huch RA, Mundinger A, Decker T, Tausch C, Dammann F, Baltzer PA, Fallenberg EM, Foschini MP, Dellas S, Knauer M, Malhaire C, Sonnenschein M, Boos A, Morris E, Varga Z (2019) Second International Consensus
Conference on lesions of uncertain malignant potential in the breast (B3 lesions). Breast Cancer Res Treat 174:279-296. https://doi.org/ 10.1007/s10549-018-05071-1

70. Rakha E, Hoon Tan P, Ellis I, Quinn C (2021). Adenomyoepithelioma of the breast: a proposal for classification Histopathology. https://doi.org/10.1111/his.14380

71. Rakha EA (2016) Morphogenesis of the papillary lesions of the breast: phenotypic observation. J Clin Pathol 69:64-69. https://doi. org/10.1136/jclinpath-2015-203191

72. Rakha EA, Abbas A, Sheeran R (2016) Invasive lobular carcinoma mimicking papillary carcinoma: a report of three cases. Pathobiology 83:221-227. https://doi.org/10.1159/000442884

73. Rakha EA, Badve S, Eusebi V, Reis-Filho JS, Fox SB, Dabbs DJ, Decker T, Hodi Z, Ichihara S, Lee AH, Palacios J, Richardson AL, Vincent-Salomon A, Schmitt FC, Tan PH, Tse GM, Ellis IO (2016) Breast lesions of uncertain malignant nature and limited metastatic potential: proposals to improve their recognition and clinical management. Histopathology 68:45-56. https://doi.org/10.1111/his. 12861

74. Rakha EA, Ellis IO (2018) Diagnostic challenges in papillary lesions of the breast. Pathology 50:100-110. https://doi.org/10.1016/j. pathol.2017.10.005

75. Rakha EA, Gandhi N, Climent F, van Deurzen CH, Haider SA, Dunk L, Lee AH, Macmillan D, Ellis IO (2011) Encapsulated papillary carcinoma of the breast: an invasive tumor with excellent prognosis. Am J Surg Pathol 35:1093-1103. https://doi.org/10.1097/PAS. 0b013e31821b3f65

76. Rakha EA, Varga Z, Elsheik S, Ellis IO (2015) High-grade encapsulated papillary carcinoma of the breast: an under-recognized entity. Histopathology 66:740-746. https://doi.org/10.1111/his.12591

77. RCPath (2016) The Royal College of Pathologists. Guidelines for non-operative diagnostic procedures and reporting in breast cancer screening. https://www.rcpath.org/uploads/assets/4b16f19c-f7bd456c-b212f557f8040f66/G150-Non-op-reporting-breast-cancerscreening-Feb17.pdf

78. Rosen PP, Caicco JA (1986) Florid papillomatosis of the nipple. A study of 51 patients, including nine with mammary carcinoma. Am J Surg Pathol 10:87-101

79. Roviello G, D’Angelo A, Sciortino M, Mini E, Nobili S, De Logu F, Massi D (2020) TRK fusion positive cancers: from first clinical data of a TRK inhibitor to future directions. Crit Rev Oncol Hematol 152:103011. https://doi.org/10.1016/j.critrevonc.2020.103011

80. Shui R, Cheng Y, Bai Q, Yang W (2017) Secretory breast carcinoma with a papillary-predominant pattern: an unusual morphological variant. Histopathology 71:488-493. https://doi.org/10.1111/his. 13232

81. Tabar L, Vitak B, Chen HH, Duffy SW, Yen MF, Chiang CF, Krusemo UB, Tot T, Smith RA (2000) The Swedish Two-County Trial twenty years later. Updated mortality results and new insights from long-term follow-up Radiol Clin North Am 38:625-651. https://doi.org/10.1016/s0033-8389(05)70191-3

82. Tavassoli FA, Eusebi V (2009) Carcinomas of low-grade malignancy. In: Silverberg SG, Sobin LH, Gardner WA (eds) Tumors of the mammary gland American Registry of Pathology in collaboration with Armed Forces Institute of Pathology Washington D.C, series 4, pp 194-195

83. Tay TKY, Tan PH (2021) Papillary neoplasms of the breast-reviewing the spectrum. Mod Pathol 34:1044-1061. https://doi.org/10. 1038/s41379-020-00732-3

84. Tognon C, Knezevich SR, Huntsman D, Roskelley CD, Melnyk N, Mathers JA, Becker L, Carneiro F, MacPherson N, Horsman D, Poremba C, Sorensen PH (2002) Expression of the ETV6-NTRK3 gene fusion as a primary event in human secretory breast carcinoma. 
Cancer Cell 2:367-376. https://doi.org/10.1016/s1535-6108(02) 00180-0

85. Troxell ML, Boulos F, Denkert C, Horii R, Yamaguchi R (2019) Intraductal papilloma. In: WHO classification of tumours editorial board. Breast Tumours, Lyon (France), International Agency for Research on Cancer (WHO classification of tumours series, 5th edn, vol 2), pp 52-56

86. Turashvili G, Brogi E, Morrow M, Hudis C, Dickler M, Norton L, Wen HY (2017) The 21-gene recurrence score in special histologic subtypes of breast cancer with favorable prognosis. Breast Cancer Res Treat 165:65-76. https://doi.org/10.1007/s10549-017-4326-1

87. Vasudev P, Onuma K (2011) Secretory breast carcinoma: unique, triple-negative carcinoma with a favorable prognosis and characteristic molecular expression. Arch Pathol Lab Med 135:1606-1610. https://doi.org/10.5858/arpa.2010-0351-RS

88. Wei S (2016) Papillary lesions of the breast: an update. Arch Pathol Lab Med 140:628-643. https://doi.org/10.5858/arpa.2015-0092-RA

89. Weiss LM, Funari VA (2021) NTRK fusions and Trk proteins: what are they and how to test for them. Hum Pathol 112:59-69. https:// doi.org/10.1016/j.humpath.2021.03.007

90. Wen HY, Desmedt C, Reis-Filho JS, Schmitt F (2019) Mucinous cystadenocarcinoma. In: WHO classification of tumours editorial board. Breast Tumours, Lyon (France), International Agency for Research on Cancer (WHO classification of tumours series, 5th edn, vol 2), pp 126-127

91. Wilsher MJ, Desai AJ, Pinder SE (2020) Low-grade adenosquamous carcinoma arising in association with a nipple adenoma. Histopathology 76:784-787. https://doi.org/10.1111/his.14033
92. Wynveen CA, Nehhozina T, Akram M, Hassan M, Norton L, Van Zee KJ, Brogi E (2011) Intracystic papillary carcinoma of the breast: an in situ or invasive tumor? Results of immunohistochemical analysis and clinical follow-up Am J Surg Pathol 35:1-14. https://doi.org/ 10.1097/PAS.0b013e3181fbe20a

93. Yoshida M, Tsuda H, Yamamoto S, Kinoshita T, Akashi-Tanaka S, Hojo T, Fukutomi T (2012) Loss of heterozygosity on chromosome 16q suggests malignancy in core needle biopsy specimens of intraductal papillary breast lesions. Virchows Arch 460:497-504. https://doi.org/10.1007/s00428-012-1200-8

94. Zhong E, Scognamiglio T, D’Alfonso T, Song W, Tran H, Baek I, Hoda SA (2019) Breast tumor resembling the tall cell variant of papillary thyroid carcinoma: molecular characterization by nextgeneration sequencing and histopathological comparison with tall cell papillary carcinoma of thyroid. Int J Surg Pathol 27:134-141. https://doi.org/10.1177/1066896918800779

95. Zhou S, Yang F, Bai Q, Li A, Li M, Zhong S, Lv H, Shui R, Tu X, Bi R, Xu X, Cheng Y, Yu B, Tang S, Sun X, Zhou X, Yang W (2020) Intense basolateral membrane staining indicates HER2 positivity in invasive micropapillary breast carcinoma. Mod Pathol 33:1275-1286. https://doi.org/10.1038/s41379-020-0461-z

Publisher's note Springer Nature remains neutral with regard to jurisdictional claims in published maps and institutional affiliations. 